WORKING PAPER

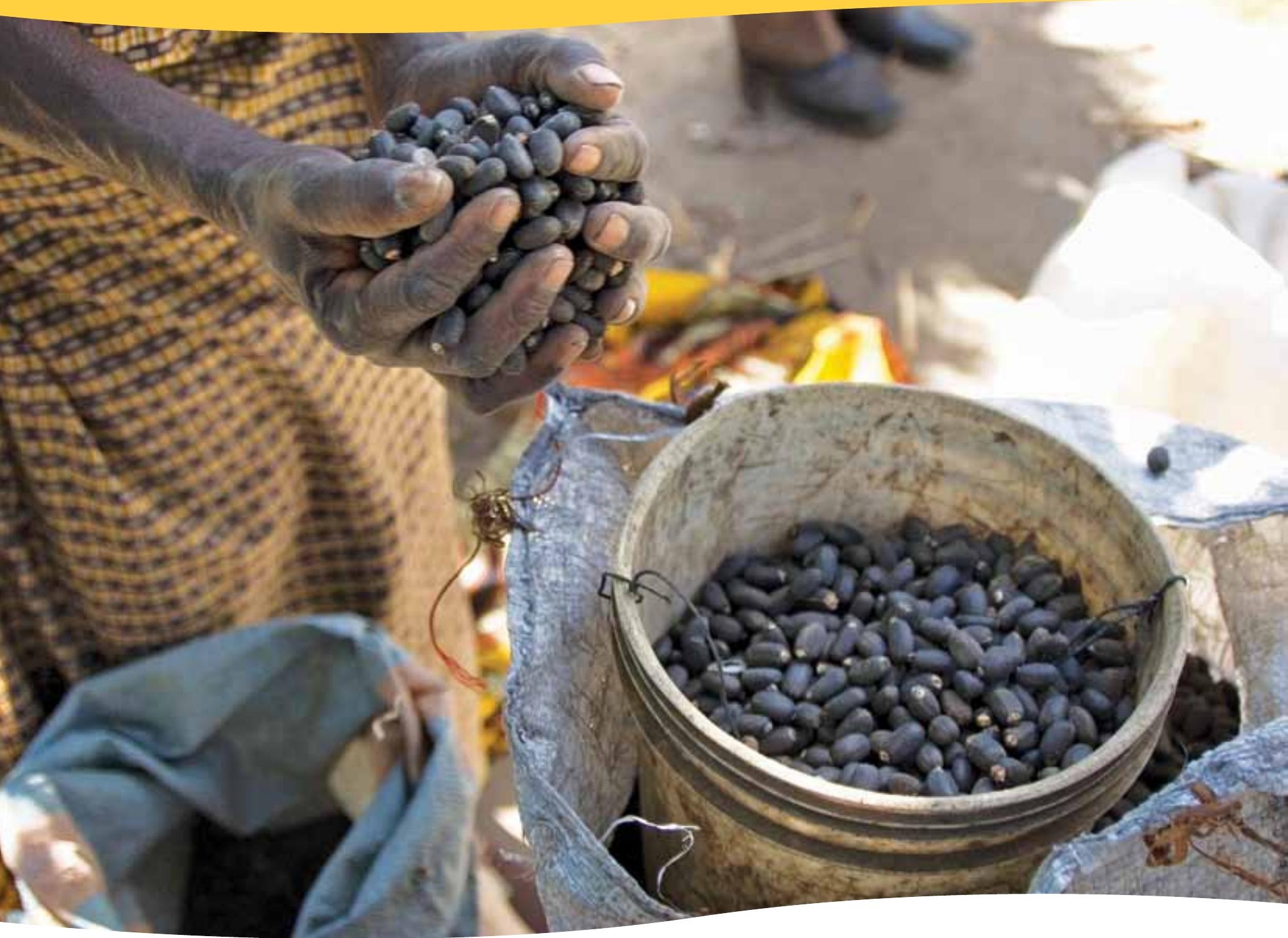

Enhancing financiers' accountability for the social and environmental impacts of biofuels

Jan Willem van Gelder

Denise Kouwenhoven

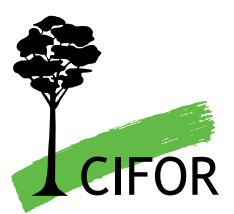





\section{Enhancing financiers' accountability for the social and environmental impacts of biofuels}

Jan Willem van Gelder

Denise Kouwenhoven 


\section{Working Paper 60}

C 2011 Center for International Forestry Research

All rights reserved

\section{Cover photo by Jeff Walker}

van Gelder, J.W. and Kouwenhoven, D. 2011 Enhancing financiers' accountability for the social and environmental impacts of biofuels. Working Paper 60. CIFOR, Bogor, Indonesia

This paper has been produced with the financial assistance of the European Union, under a project titled, 'Bioenergy, sustainability and trade-offs: Can we avoid deforestation while promoting bioenergy?' The objective of the project is to contribute to sustainable bioenergy development that benefits local people in developing countries, minimises negative impacts on local environments and rural livelihoods, and contributes to global climate change mitigation. The project will achieve this by producing and communicating policy relevant analyses that can inform government, corporate and civil society decision-making related to bioenergy development and its effects on forests and livelihoods. The project is managed by CIFOR and implemented in collaboration with the Council on Scientific and Industrial Research (South Africa), Joanneum Research (Austria), the Universidad Nacional Autónoma de México and the Stockholm Environment Institute. The views expressed herein can in no way be taken to reflect the official opinion of the European Union.

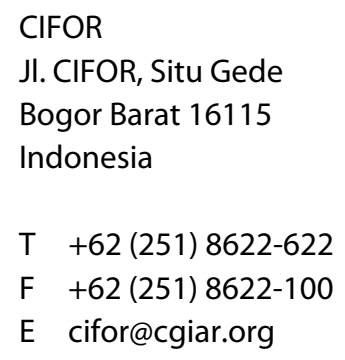

www.cifor.cgiar.org

Any views expressed in this publication are those of the authors. They do not necessarily represent the views of CIFOR, the authors' institutions or the financial sponsors of this publication. 


\section{Table of contents}

Executive summary $\quad$ v

1. Financing biofuel investments in Asia, Latin America and Africa 1

1.1 Growth of biofuel production and consumption 1

1.2 Expected future growth of global biofuel production 3

1.3 Potential benefits and hazards for developing countries 4

1.4 The roles of financiers $\quad 5$

1.5 Research approach to assess investments and financiers 5

1.6 Investment volumes 6

1.7 Companies and financiers involved $\quad 8$

2. Responsible financing by private and public financiers 12

2.1 What is responsible financing? 12

2.2 Reasons to adopt a responsible financing policy 12

2.3 Responsible financing instruments 13

2.4 Types of responsible financing policies 18

$\begin{array}{ll}2.5 \text { Effectiveness of responsible financing policies } & 19\end{array}$

2.6 Options to improve responsible biofuel financing policies 25

3. Regulatory options to strengthen responsible financing 27

$\begin{array}{ll}3.1 \text { Introduction } & 27\end{array}$

3.2 Direct regulations on biofuel financing $\quad 27$

3.3 International framework for financial regulation 28

3.4 Integrating sustainability in financial regulation $\quad 29$

3.5 Other regulatory options 31

$\begin{array}{lr}\text { 4. Conclusions } & 32\end{array}$

\begin{tabular}{lr} 
5. & References \\
\hline
\end{tabular} 


\section{List of tables, figures and boxes}

\section{Tables}

1 Total land area required to meet projected biofuel demand in $2030 \quad 3$

2 Estimated feedstock investments 2000-2009 (million US\$) 7

3 Estimated investments in biofuel production 2000-2009 (million US\$) 8

4 Importance of financial stakeholders for 20 biofuel cases $\quad 10$

\section{Figures}

1 Global ethanol production 2000-2009 (1000 barrels per day) 1

2 Biodiesel production 2000-2009 (1000 barrels a day) 2

3 Bioethanol consumption per country, 2009

4 Biodiesel consumption per country, 2009

\section{Boxes}

1 Focal ecoregions, feedstocks and countries 6

2 Multilateral development bank criteria relevant for biofuels $\quad 14$

3 Global Bioenergy Partnership $\quad 15$

4 Exclusion list of the Norwegian Government Pension Fund 17

5 Examples of collective intentional statements 18

6 Examples of single bank responsible financing policies $\quad 20$

7 Roundtable on Sustainable Biofuels (RSB) 22

$8 \quad$ IFC and Wilmar International $\quad 23$

9 Gunns pulp mill in Tasmania $\quad 25$ 


\section{Executive summary}

Twenty case studies were undertaken to analyse trends in investments and financing in the production of biofuel and of the feedstocks used for biofuel (palm oil, soybeans, sugarcane and jatropha) in forest-rich countries in Asia, Africa and Latin America. With the exception of jatropha, only a small proportion of the total investment in feedstocks production is used for biofuel production, about $18 \%$ for sugarcane, $16 \%$ for soybeans and $4 \%$ for palm oil. We estimated that in the 20 countries under scrutiny, about US\$ 2.0-2.7 billion was invested in growing feedstocks for biofuel in the period 20002009. Investments in producing biofuel from these feedstocks, in these same 20 countries, are estimated at US\$ 5.7-6.7 billion during the same period.

Nevertheless, significant investments have been made in producing biofuels only in Brazil, Indonesia, Malaysia and Colombia, and they are not important in other countries researched.

The investments in feedstocks and biofuel production were financed by private entrepreneurs, as well as by public financiers (e.g. government subsidies, multilateral development loans and grants, and investments by state-owned companies) and by private financial institutions (e.g. banks, asset managers, pension funds). A large number of private financial institutions were found to be involved, most of which are located outside the country where the investment took place. Dozens of public financiersmany of which are foreign - play a significant role.

As the availability of finance is a crucial precondition for the further growth of this sector, these actors could play an important role in leveraging more sustainability in the biofuel sector. However, our findings suggest that most private and public financiers involved are not yet effectively addressing key environmental and social sustainability challenges, either because they lack sustainability policies or because their policies are of insufficient quality.

- Only a few private financiers have developed a responsible financing policy for biofuel investments that contain verifiable and welldefined criteria. Where policies exist, they are not linked clearly to internationally accepted standards, and they lack transparent and effective internal monitoring and external compliance mechanisms.

- Amongst public financiers, only the multilaterals and a few foreign development banks have developed social and environmental policies that contain verifiable and well-defined criteria. Multilateral development banks also have transparent and effective internal monitoring and external compliance mechanisms in place, but they play a significant financing role in only a few case studies. Most other government financiers, especially domestic and foreign state-owned companies, lack both policies and monitoring and compliance mechanisms.

Realising the potential influence of private and public financiers on minimising the negative social and environmental costs associated with feedstock expansion and biofuel production requires improved dissemination of high-quality governance instruments amongst various financiers. Furthermore, the quality of governance instruments needs to be enhanced. In concrete terms, this would mean the following:

- Broad consensus is needed on a set of welldefined, verifiable criteria, preferably derived from international standards, which are of significance in shaping the economic, social and environmental impacts of biofuel and biofuel feedstock production. Independent compliance and monitoring processes for all forms of private and public investments should be set up or improved, to strengthen the implementation of responsible financing policies and correct errors made.

- Private financiers should apply their responsible financing policies and related instruments to all forms of financing (including loans and other credits, underwriting, private equity and asset management), as well as to all companies involved in the biofuel supply chain.

- Governments-both in forest-rich production countries and in consumer countries—should apply responsible financing policies to all forms of public financing (e.g. subsidies, export credits, 
development loans and investments by state-owned companies) as well as to all investments in the biofuel supply chain (domestically and abroad).

Whilst all private and public financiers involved could adopt these recommendations on a voluntary basis, governments have regulatory options to motivate or assist private financial institutions in developing and applying sound responsible financing policies. It is not realistic to develop such regulations for the feedstock and biofuel sectors alone, or to make financiers liable or responsible for the activities of the companies they finance.

A more realistic approach would be to include generic requirements to develop and apply sound responsible financing policies in financial regulation. A few countries, such as Indonesia, China and the United Kingdom, have taken steps in this direction.
As financiers for feedstock and biofuel production originate from many countries in the world, it would be most effective to include sustainability criteria in the international financial regulatory framework, especially the Basel Capital Accord (BCA). The new BCA III was agreed upon in November 2010, but implementation in EU and national legislation is still underway. This implementation process offers opportunities to include sustainability criteria in many countries' financial regulations.

Governments can also create regulations requiring increased sustainability reporting and transparency by biofuel companies, or motivate credit rating agencies to include sustainability issues in their credit ratings. When considering investments in these companies, financial institutions can then make more informed decisions. 


\section{Financing biofuel investments in Asia, Latin America and Africa}

This chapter provides an introduction to the growth of the global biofuel sector and briefly summarises the social and environmental issues related to the expansion of biofuel production, especially in forest-rich countries. This chapter also draws on the findings of separate research (Van Gelder and German 2011) exploring the different groups of financiers involved in financing investments in biofuel feedstock cultivation and biofuel production in select forest-rich countries in Asia, Africa and Latin America.

\subsection{Growth of biofuel production and consumption}

\subsubsection{Production growth 2000-2009}

The global biofuel sector grew considerably in the period 2000-2009, driven primarily by concerns about fossil fuel prices and availability, a renewed quest by many countries for energy independence, widespread awareness of the need to reduce greenhouse gas (GHG) emissions and the potential benefits of socio-economic development (UNCTAD 2009).
An overview of global ethanol production worldwide from 2000 to 2009 by main production countries is given in Figure 1.

As Figure 1 shows, global production of ethanol (which can replace gasoline) increased more than fourfold from 299000 barrels a day in 2000 to 1.3 million barrels a day in 2009. The United States (54\% of global production) and Brazil (34\%) are by far the largest ethanol producers in the world. In Europe (5\%), France and Germany are the main producers.

In turn, global biodiesel production grew even more rapidly in the past decade. An overview of global biodiesel production volumes worldwide from 2000 to 2009 , by main production countries, is given in Figure 2.

As Figure 2 shows, biodiesel production increased 18fold from 16000 barrels a day in 2000 to 308000 barrels a day in 2009. The main biodiesel producers in the world are Germany (17\%), France (13\%) and the United States (11\%). The EU as a whole accounts for $56 \%$ of global biodiesel production.

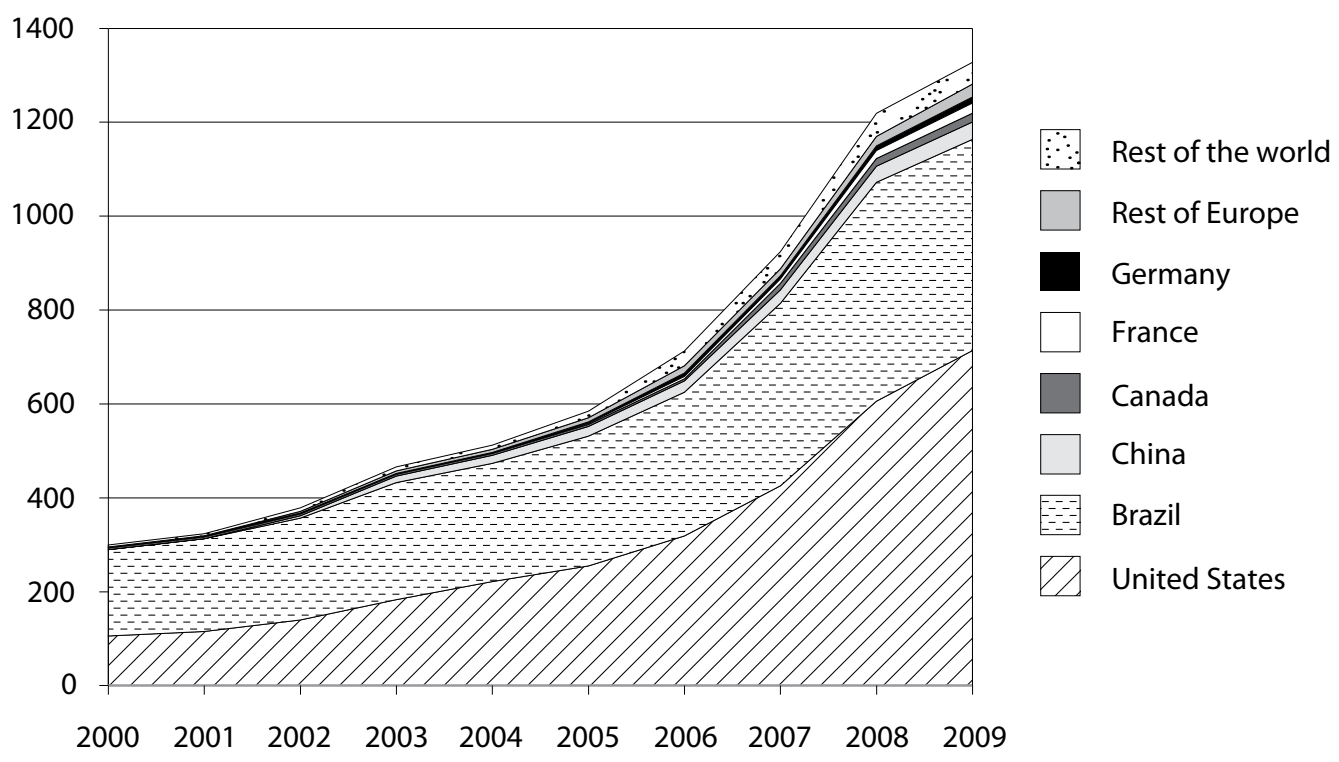

Figure 1. Global ethanol production 2000-2009 (1000 barrels per day) 


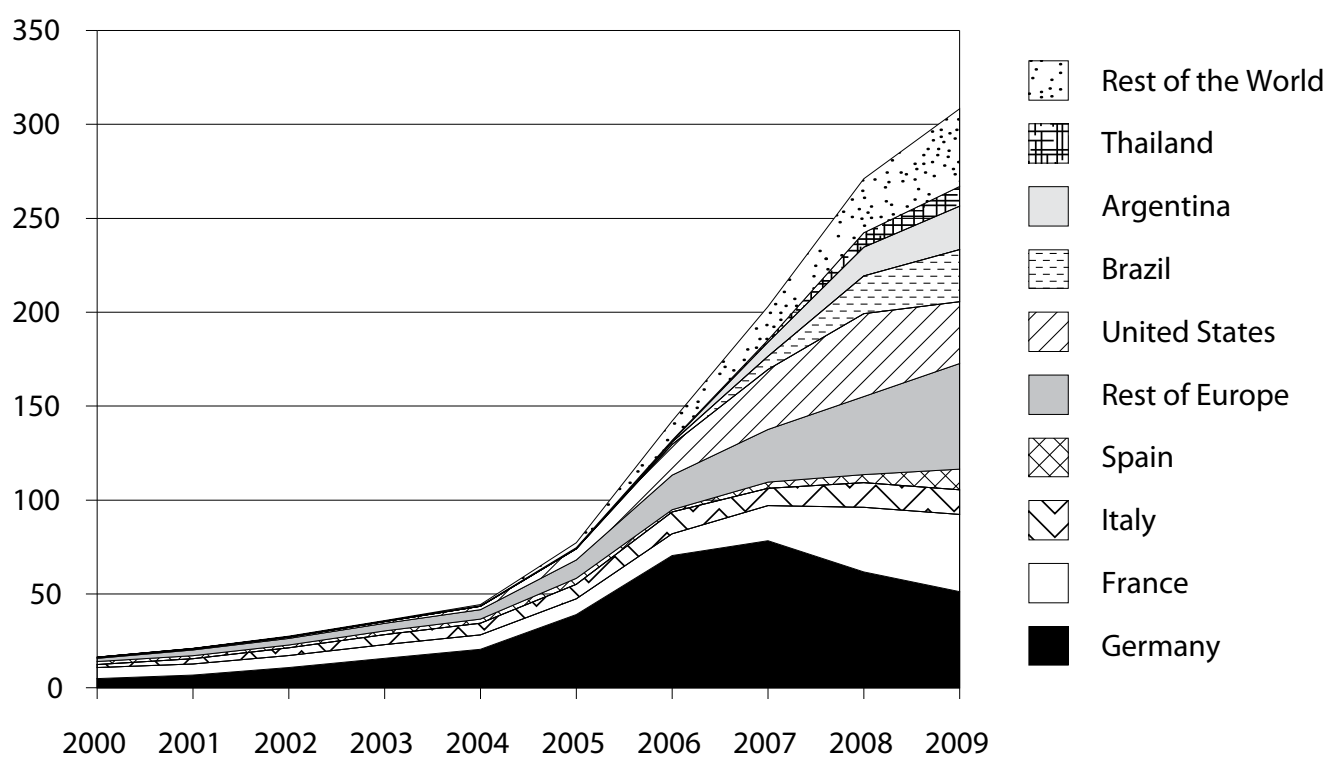

Figure 2. Biodiesel production 2000-2009 (1000 barrels a day)

Source: US Energy Information Administration, International Energy Statistics [accessed March 2011]

\subsubsection{Consumption per country}

In bioethanol consumption the United States and Brazil lead the way, together accounting for $87 \%$ of global bioethanol consumption. The EU plays a relatively small role, accounting for only $5 \%$ of bioethanol consumption worldwide.

An overview of global ethanol consumption in 2009 by the main consuming countries is given in Figure 3.

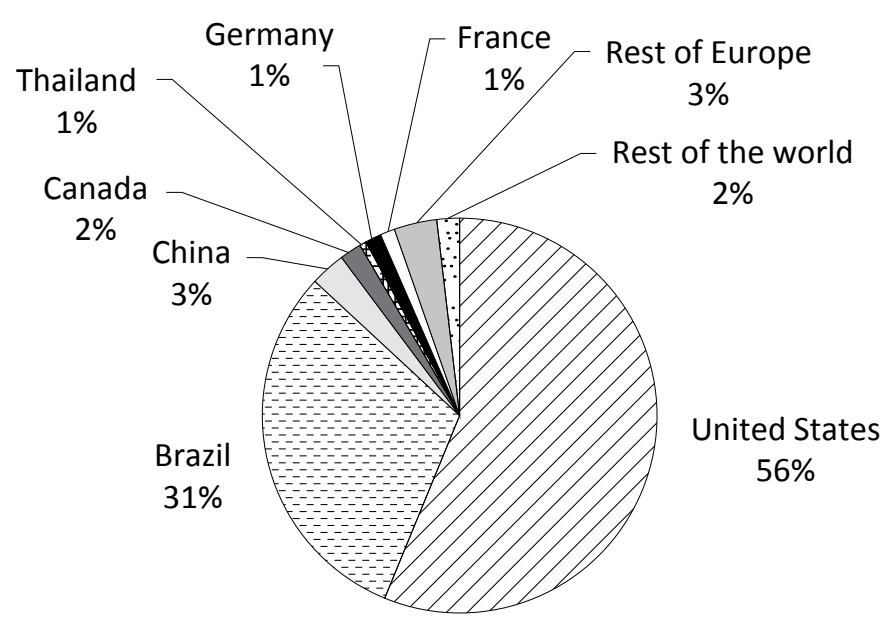

Figure 3. Bioethanol consumption per country, 2009

Source: US Energy Information Administration, International Energy Statistics [accessed March 2011]
Biodiesel consumption patterns differ greatly from the ethanol consumption patterns, as shown in Figure 3. An overview of global biodiesel consumption in 2009 by the main consuming countries is given in Figure 4.

As Figure 4 shows, the European Union is by far the world's largest biodiesel consumer (accounting for $70 \%$ of global biodiesel consumption), with France,

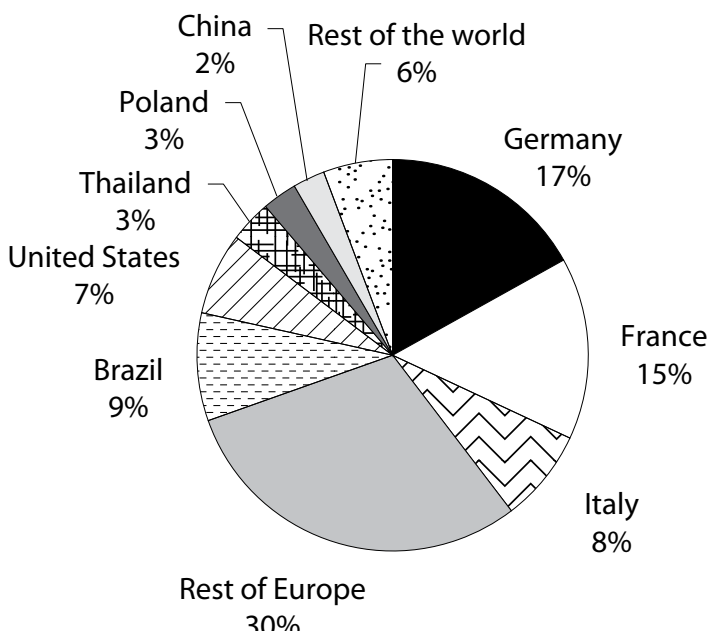

Figure 4. Biodiesel consumption per country, 2009

Source: US Energy Information Administration, International Energy Statistics [accessed March 2011] 
Germany and Italy being the largest consumers within Europe. Brazil (accounting for 9\% of global biodiesel consumption) and the United States (accounting for 7\%) follow.

\subsection{Expected future growth of global biofuel production}

Further growth of biofuel production and consumption is expected, spurred by new policy initiatives in various markets. One of the most important initiatives is the Renewable Energy Directive (EU-RED), on which the EU agreed in April 2009. This directive establishes an overall EU target for 2020 of $20 \%$ renewable energy and individual targets of $10 \%$ renewable energy in the transport sector of each member state (EU 2009). According to estimates used by the EU's Directorate of Transportation and Energy, 1195 Mtoe (million tonnes of oil equivalent) of biomass will be needed to meet these targets (Ragwitz et al. 2009), doubling the current use of biomass. Some 173 Mtoe of the needed biomass is expected to come from EU sources, with the remaining 22 Mtoe supplied by imports.

Global use of bioethanol and biodiesel is estimated to nearly double from 2005-2007 to 2017. Ethanol production is estimated to reach 127 billion litres and biodiesel 24 billion litres by 2017. Most of this increase will be due to biofuel use in the United States, the EU, Brazil and China. However, other countries could also develop significant biofuel consumption. Indonesia, India, Australia, Canada, Thailand, the Philippines and Japan are all likely to become important producers and consumers in the near future (UNEP 2009).

Oil company BP expects global biofuel production to increase fourfold from 58.6 Mtoe in 2010 to
235.1 Mtoe in 2030. This implies a growth of 300\% in the coming 20 years (BP 2010).

The realisation of these future growth scenarios depends largely on the availability of land appropriate for producing the various feedstocks. Several factors, apart from the rise in biofuel demand, will further increase the pressure on available land. These factors include changing global diets, water shortage, future yield developments and climate change (UNEP 2009).

Land use for biofuel production was estimated to be around 13.8 million hectares (Mha) in 2004, accounting for about $1 \%$ of the current global area under crop. By 2007, it was estimated at 26.6 Mha. Several estimates are available for the land area required to meet various future targets. These estimates are, however, highly uncertain as they depend on a number of variable factors such as the biofuel crop selected, production practices, projected feedstock yields and market and policy incentives. Ravindranath et al. (2009) have estimated the land required for biofuel production, if biofuels were to substitute for $10 \%$ of the projected fossil fuel demand for transportation in 2030. All estimates refer to a single crop scenario: the land use needed if $10 \%$ of global biodiesel or bioethanol demand were met by biofuel from a single crop. The results are summarised in Table 1.

As Table 1 shows, estimates for global land requirements range from 40 Mha for oil palm to 299 Mha for soybean. Clearly several combinations of these crops are feasible. Projections of the area likely to be under biofuel crops by 2030 range from 201 Mha (when a combination of jatropha and sugarcane is considered) to $421 \mathrm{Mha}$ (when a combination of soybean and maize is considered), accounting for $14.4 \%$ and $30.2 \%$, respectively, of global arable land in 2030 (Ravindranath et al. 2009).

Table 1. Total land area required to meet projected biofuel demand in $\mathbf{2 0 3 0}$

\begin{tabular}{lcccccc}
\hline Region & \multicolumn{2}{c}{$\begin{array}{c}\text { Land requirement to meet 10\% of biodiesel } \\
\text { demand, in Mha }\end{array}$} & \multicolumn{2}{c}{$\begin{array}{c}\text { Land requirement to meet 10\% of bioethanol } \\
\text { demand, in Mha }\end{array}$} \\
\cline { 2 - 8 } & Jatropha & Oil palm & Soybean & Maize & Sugarcane & $\begin{array}{c}\text { Sweet } \\
\text { sorghum }\end{array}$ \\
\hline OECD & 73 & 20 & 152 & 62 & 29 & 49 \\
Non-OECD & 70 & 20 & 147 & 60 & 28 & 47 \\
\hline World & 143 & 40 & 299 & 122 & 58 & 96 \\
\hline
\end{tabular}

Source: Ravindranath et al. (2009) 


\subsection{Potential benefits and hazards for developing countries}

Most developing countries, with the exception of Brazil and Argentina, do not play a significant role in supplying the main markets for biofuels in Europe and North America, as shown in Figure 1 and Figure 2.

However, developing countries do increasingly supply foreign markets with feedstocks to be converted into biofuels abroad. At present, 13\% of Europe's feedstock demand for biodiesel production is met by soybean oil imports, with $5 \%$ met by palm oil imports (Van Gelder and German 2011). Europe, India and China, with their growing demand for biodiesel, are projected to import increasing volumes of feedstocks from developing countries (MVO 2009). In addition, several developing countries are increasing biofuel production to meet domestic demand and replace expensive and polluting fossil fuel imports.

These developments bring great potential benefits for developing countries, including socio-economic development (i.e. income distribution, land rights, skills training and availability of finance), lower GHG emissions and a reduction in energy dependence. Cortez and Regis Leal (2010) argue that in the jatropha sector in Zambia, for example, biofuels especially serve to reduce energy independence, improve rural livelihoods and enhance the agriculture sector.

However, especially in the case of first-generation biofuels produced from agricultural crops, many studies point to a number of potential hazards as well. To be a viable alternative to fossil fuels, biofuels must have a positive energy output, have environmental and social benefits, be economically competitive and not compete with food supply (Hill et al. 2006). Amongst the potential hazards are the inability of biofuels to mitigate climate change effectively, negative impacts on food availability and on land and water use and availability, and negative impacts on forests and other natural habitats (Fearnside 2001).

Several studies indicate that estimates of GHG emissions reductions that the use of biofuels can contribute to, can differ according to the feedstocks they are derived from — and such reductions will not always be substantial. Especially in the case of corn, soy and oil palm, the net gain in GHG emissions can be limited (UNEP 2009, Pena et al. 2010). According to Pimentel et al. (2010), the net return on energy from soybean oil is positive only when the soybean is grown without commercial nitrogen fertiliser. The authors argue that although palm oil has a better return than soybean biodiesel and corn ethanol, the net energy output could still be negative (Pimentel et al. 2010). The net resulting balance decreases even more when areas that were not previously cultivated are converted to biofuel feedstock production (Beer et al. 2007).

The indirect effects of biofuel production, including the destruction of natural habitats to expand production of biofuel feedstocks, may have greater climate impacts than the direct effects (Delucchi 2006, Buchanan et al. 2008). In the case of oil palm, for example, major drawbacks are the increase of $\mathrm{CO}_{2}$ caused by removing tropical rainforests and reducing biodiversity of the ecosystem (Koh and Wilcove 2008, Pimentel et al. 2010).

The rapid growth of commercial biofuel production may result in poorer groups losing access to the land on which they depend, especially when competing resource claims exist amongst local farmers, governments and new biofuel producers, and when appropriate conditions are not in place, This development potentially endangers food security (Peskett et al. 2007, Cotula et al. 2008, Oxfam 2008, SEI and HIVOS 2008, Fischer et al. 2009, ActionAid 2010, Burley and Bebb 2010).

The potential negative impact of biofuel production on food security peaked in 2007/2008, when food prices rose to alarming levels (Rosillo-Calle and Johnson 2010). Demand for biofuel feedstock was partially blamed for the high food prices, although researchers disagree over the validity of this argument. Recent studies have pointed out that when food yields are stagnating, and consumption patterns in developing countries are likely to continue to shifts towards more meat and dairy, significantly more crop and pasture land is required. The additional demand for cropland generated by first-generation biofuels only exacerbates this problem (UNEP 2009). 
Based on 6 field studies on the impacts of biofuel developments in Southeast Asia, sub-Saharan Africa and Latin America, German et al. (2010) conclude that uneven local livelihood impacts are the norm. The winners tend to be those that can best afford upfront investments in feedstock cultivation and plantation employees. The losers tend to be customary land users whose livelihoods are undermined by plantation expansion and who face the greatest difficulty in capturing benefits (German et al. 2010).

\subsection{The roles of financiers}

Against the background of the rapid growth of the global production of (feedstocks for) biofuels (see section 1.1), this report explores the roles that various groups of financiers played in enabling this development during 2000-2009. Because this development brings not only potential benefits but also strong potential hazards (see section 1.3), this report further explores options to enhance the accountability of financiers for the social and environmental impacts of (feedstocks for) biofuel production.

Companies that produce biofuels and feedstocks for biofuel had to make large investments to realise the production growth in the past decade. These investments were needed to acquire or build land, infrastructure, machinery, storage and processing facilities. In addition to these investments, which are used for a number of years, companies have annual costs for labour, seeds, fertiliser and other inputs. These annual costs are usually paid out of the company's cash-flow and are not seen as investments.

It is likely that the investments were partly financed by the private owners of (the mostly smaller) companies active in feedstock and biofuel production. However, as many larger companies are also active in feedstock and biofuel production, not all companies are (fully) owned by private entrepreneurs. Larger companies may be (partly) owned by governments or by institutional investors (e.g. pension funds, investment funds and private equity funds). These institutional and governmental owners of companies are then also involved in financing the investments made by feedstock- and biofuel-producing companies.
In addition to the equity supplied by their owners, companies often finance their investmentsincluding for biofuel and feedstock productionwith loans from commercial banks, national development banks, multilateral banks and other financial institutions (Roberts 2009).

The sheer size of the investments made in feedstock and biofuel production makes it likely that various groups of financiers (private entrepreneurs, private and public banks, institutional investors and governments) are involved. Without the active involvement of these financiers, the recent growth of the biofuel sector would not have been feasible and current growth rates could not be sustained. These financiers therefore share the responsibility for minimising the negative social and environmental impacts of the sector, as described in section 1.3.

Because strong further growth is predicted, for which the availability of finance is a crucial precondition, the various financiers could play an important role in leveraging more sustainable and equitable development pathways in the biofuel sector.

\subsection{Research approach to assess investments and financiers}

To identify which groups of financiers are involved in financing feedstock and biofuel investments, a collaborative research effort was undertaken in 2010 by Profundo, the Yale School of Forestry and Environmental Studies and the Center for International Forestry Research (CIFOR) (Van Gelder and German 2011). The following provides a brief overview of the methodology of this research project as well as findings on trends in biofuel investments and financing.

One of the main concerns with regard to increasing feedstock production for biofuels is its possible negative impact on forests and natural habitats (see section 1.3), which obviously is of great concern for CIFOR. We therefore selected 20 biofuel feedstock sectors spread over 16 forest-rich countries in Asia, Africa and Latin America. The countries are located in important forest ecoregions in developing countries: the Amazon Basin; the Congo Basin; the humid tropical forests of Southeast Asia; and the dry forests of Africa, Asia and Mesoamerica. Within each 
ecoregion, a few countries with significant existing or emerging activities in the production of feedstocks for biofuel were selected (Box 1).

We researched the following aspects for the 20 feedstock case studies for the period 2000-2009:

- The 10 most important feedstock-growing or -trading companies in terms of total assets, as well as the 10 most important biofuel producers using this feedstock (for countries where actual investments in biofuel production have taken place). For each company we describe the scope and scale of activities, country of origin and ownership and investments made in the past 10 years.

- Institutions and individuals that financed these companies' investments, including foreign and domestic governments, entrepreneurs, institutional investors and banks, and multilateral financial institutions.

A variety of information sources was used, including scientific studies; consultancy and market research reports; government statistics and publications; company websites, annual reports and other publications; articles in the financial media; specialised financial databases and local media and NGO reports.

Box 1. Focal ecoregions, feedstocks and countries

\section{African (dry) forests}

- Jatropha in Ghana, Madagascar, Mozambique, Tanzania and Zambia

- Sugarcane in Malawi, Mozambique, Tanzania and Zambia

\section{Amazon Basin}

- Oil palm in Colombia

- Soy in Bolivia and Brazil

- Sugarcane in Brazil

\section{Congo Basin}

- Oil palm in Cameroon, Democratic Republic of Congo and Republic of Congo

\section{Humid tropical forests of southeast Asia}

- Oil palm in Indonesia and Malaysia

Other dry forest ecoregions (mesoamerica, Asia)

- Jatropha in Mexico and India
Reliable financial data were not available for all major companies researched. Furthermore, our focus on the 10 largest companies in each study in some cases excluded a significant part of the market occupied by a larger number of smaller companies. Despite these methodological shortcomings, we extrapolated investment figures and sources of finance for the most important companies to estimate total investments in the entire sector in the study period (see section 1.6).

We also conducted an analysis to identify patterns in the types of companies active in different countries and feedstock sectors. The sources of finance were also analysed, with an aim of identifying trends amongst the groups of financiers. These analyses are discussed in section 1.7.

\subsection{Investment volumes}

\subsubsection{Investment volumes in feedstock production}

Investment volumes during 2000-2009 for the production of 4 feedstocks (sugarcane, palm oil, soybeans and jatropha) in 16 countries are provided in Table 2. As oil palm is a perennial crop requiring large up-front investments in plantation expansion, much more was invested in the 6 countries with oil palm cultivation than in the 5 countries with sugarcane. In the 2 countries growing soybean and the 7 growing jatropha, investment volumes were much smaller. This is related both to the investment costs per hectare and the amount of land brought under cultivation (Van Gelder and German 2011).

With the exception of jatropha (which is grown only as biofuel feedstock), on a global scale only a small portion of the feedstocks is used for biofuels: $18 \%$ for sugarcane, $16 \%$ for soy oil and $4 \%$ for palm oil (Van Gelder and German 2011). This means that many of the investments in feedstock expansion listed in Table 2 are not linked directly to biofuel demand, but rather to demand from the food, feed and other sectors. Of course, the percentage of the feedstock yield used for biofuel production varies from country to country. Demand from biofuel producers might therefore be a more significant driver of expansion in some specific countries than these average percentages suggest. 
Table 2. Estimated feedstock investments 2000-2009 (million US\$)

\begin{tabular}{|c|c|c|c|c|c|}
\hline Country & Sugarcane & Jatropha & Palm oil & Soy & Total \\
\hline Cameroon & & & $2-4$ & & $2-4$ \\
\hline Congo & & & $1-2$ & & $1-2$ \\
\hline DR Congo & & & $40-60$ & & $40-60$ \\
\hline Ghana & & $3-5$ & & & $3-5$ \\
\hline Madagascar & & $25-40$ & & & $25-40$ \\
\hline Malawi & $60-70$ & & & & $60-70$ \\
\hline Mozambique & $100-120$ & $5-8$ & & & $105-128$ \\
\hline Tanzania & $100-120$ & $5-8$ & & & $105-128$ \\
\hline Zambia & $20-25$ & $12-20$ & & & $32-45$ \\
\hline Total for Africa & $280-335$ & $50-81$ & $43-66$ & & $373-482$ \\
\hline India & & $120-200$ & & & $120-200$ \\
\hline Indonesia & & & $10000-15000$ & & $10000-15000$ \\
\hline Malaysia & & & $8000-12000$ & & $8000-12000$ \\
\hline Total for Asia & & $120-200$ & $18000-27000$ & & $18120-27200$ \\
\hline Bolivia & & & & $200-300$ & $200-300$ \\
\hline Brazil & $4000-5000$ & & & $1500-1800$ & $5500-6800$ \\
\hline Colombia & & & $700-1000$ & & $700-1000$ \\
\hline Mexico & & $5-9$ & & & $5-9$ \\
\hline Total for Latin America & $4000-5000$ & $5-9$ & $700-1000$ & $1700-2100$ & $6405-8109$ \\
\hline Total & $4280-5335$ & $175-290$ & $18743-28066$ & $1700-2100$ & $24898-35791$ \\
\hline
\end{tabular}

Source: Van Gelder and German (2011)

Investment estimates are fairly uncertain because of a lack of reliable sources; nevertheless, for the 20 case studies researched, an estimated total sum of US\$ 25-35 billion was invested in growing feedstock from 2000 (Table 2). For most investments in multi-purpose feedstocks, the tendency for decisions on end markets to be made at harvest time makes it impossible to differentiate between investments for the fuel market and those for the food market; nevertheless, we have used the above approximate percentages - $100 \%$ for jatropha, $18 \%$ for sugarcane, $16 \%$ for soy oil and $4 \%$ for palm oil-to estimate which part of the investment volumes in these feedstocks was driven by biofuel purposes. For the 20 case studies, we estimate that, in the period 2000-2009, in the order of US\$ 2.0-2.7 billion was invested in growing feedstocks for biofuel (Van Gelder and German 2011).

\subsubsection{Investment volumes in biofuel}

In our 20 case studies, the investments made in the period 2000-2009 to produce biofuel from the selected feedstocks were higher than the investments in growing the feedstocks: around US\$ 5.7-6.7 billion since 2000 in 6 out of 20 case studies (Table 3; in the other 14 cases, no investments in biofuel production were found).

The bulk of the investments found in the 6 case studies (US\$ 3.8-4.2 billion) was invested in sugarbased ethanol production in Brazil, an industry that has been in operation for several decades. Significant amounts were also invested in palm-based biodiesel in Indonesia, Malaysia and Colombia and soy-based biodiesel in Brazil. In other countries researched, only small or negligible investments in biofuel production have been made to date.

For countries expanding sugarcane production, more domestic investments in ethanol production are expected in the near future. International trade in sugarcane for foreign ethanol production is almost non-existent, whereas ethanol is increasingly traded internationally. This offers opportunities to capture added value and stimulate economic growth. 
Table 3. Estimated investments in biofuel production 2000-2009 (million US\$)

\begin{tabular}{|c|c|c|c|c|c|}
\hline Country & $\begin{array}{c}\text { Sugar-based } \\
\text { ethanol }\end{array}$ & $\begin{array}{c}\text { Jatropha-based } \\
\text { biodiesel }\end{array}$ & $\begin{array}{l}\text { Palm-based } \\
\text { biodiesel }\end{array}$ & $\begin{array}{c}\text { Soy-based } \\
\text { biodiesel }\end{array}$ & Total \\
\hline Malawi & $8-10$ & & & & \\
\hline Mozambique & & $14-18$ & & & \\
\hline Total for Africa & $8-10$ & $14-18$ & & & $22-28$ \\
\hline Indonesia & & & $800-1000$ & & \\
\hline Malaysia & & & $250-350$ & & \\
\hline Total for Asia & & & $1050-1350$ & & $1050-1350$ \\
\hline Brazil & $3800-4200$ & & & $700-900$ & $4500-5100$ \\
\hline Colombia & & & $150-250$ & & $150-250$ \\
\hline Total for Latin America & $3800-4200$ & & & & $4650-5350$ \\
\hline Total & $3808-4210$ & $14-18$ & $1200-1600$ & $700-900$ & $5722-6728$ \\
\hline
\end{tabular}

Source: Van Gelder and German (2011)

For countries producing biodiesel feedstocks (i.e. palm oil, soy oil and jatropha), the situation is less clear-cut. In some countries, biodiesel feedstocks will be processed into biodiesel domestically, especially when a large domestic or regional biodiesel market is developing as a result of targeted government policies (e.g. Brazil, India, Indonesia). For many other countries, especially in Africa, it seems likely that the biodiesel feedstocks they produce (palm oil, jatropha oil) will be exported directly and processed into biodiesel in foreign consumer markets. This last investment pattern will clearly give developing countries fewer opportunities to capture added value than in the case of ethanol production (Van Gelder and German 2011).

\subsection{Companies and financiers involved}

\subsubsection{Types of company involved}

Different types of company are driving the expansion of feedstock and biofuel production in the 20 country-feedstock pairs studied, patterns which in large part reflect the maturity of the sector. The expansion of sugarcane production is dominated by the existing sugar industry sector. In Brazil, the sector is already mature and the largest players are domestic - mostly cooperatives and some largescale private companies. In the 4 African countries researched, the sugar industry is less advanced and foreign producers from South Africa and France are dominant. As there is a high level of integration between sugar and ethanol production, the expansion of sugar-based ethanol is driven mainly by the same companies in all 5 countries. Start-up companies play a significant role only in Mozambican ethanol production (Van Gelder and German 2011).

In Indonesia and Malaysia, the oil palm plantation sector is very mature. Expansion of feedstock production is driven mainly by existing plantation companies, both domestic and foreign. In Colombia, domestic oil palm plantation companies dominate, but in African countries with an emerging oil palm sector (e.g. Cameroon, Congo, the DRC), foreign companies are dominant. Several of these are active in the oil palm industry elsewhere, but in Congo and the DRC many of the foreign financiers originate from other sectors (such as the Chinese electronics company ZTE in the DRC and the Italian oil company ENI in Congo). Palm-based biodiesel expansion is driven mostly by companies active in the oil palm plantation sector, which are now investing downstream. In Indonesia, companies from other sectors, such as oil company Pertamina, also play an important role. The role of start-ups is relatively small in all countries researched.

This is clearly different from the jatropha feedstock sector, which is a very new sector in all 7 countries researched (Ghana, India, Madagascar, Mexico, Mozambique, Tanzania and Zambia). Existing biofuel producers (already active in biofuels elsewhere) and start-up companies dominate. Most of these start-up companies are managed by foreign entrepreneurs; only in Ghana do domestic start-ups 
play a significant role. Companies from other sectors (domestic oil companies) are important in India. In none of these countries have significant investments in jatropha-based biodiesel yet taken place. Whether these investments will materialise in all countries is also unclear; some countries may develop into exporters of jatropha feedstock to foreign biodiesel producers (Van Gelder and German 2011).

In the soybean sector, we researched only 2 countries, Brazil and Bolivia, which already have a wellestablished sector. Expansion of soybean cultivation in these countries is driven almost exclusively by existing traders, both domestic and foreign (from the United States, France, Venezuela, Peru and the Netherlands). With regard to investments in biodiesel, the 2 countries differ considerably. The soy-based biodiesel sector in Brazil is growing strongly, driven by investments from existing soybean traders, domestic start-up companies and companies from other sectors, such as oil company Petrobras. In Bolivia, investments in biodiesel are inhibited by government policies, which prevent using food products for energy uses (Van Gelder and German 2011).

\subsubsection{Forms of finance and types of financiers involved}

The companies active in feedstock or biofuel production always finance a significant part-or sometimes all_of their investments from their own cash-flow and retained earnings. As this money belongs to their shareholders, these shareholders are ultimately financing the investments. This is called equity financing.

Loans and bonds from various creditors form another source of capital used by a large proportion of the companies investing in feedstocks and biofuels. This is called debt financing.

Finally, some investments in feedstocks and biofuels have been financed by subsidies or grants from governments.

In the 20 case studies, we found the following groups of financiers providing these different forms of finance-equity, debt and subsidies/grants-thereby financing the development of feedstock growing and biofuel production in these 20 cases (Van Gelder and German 2011).
- Entrepreneurs (both domestic and foreign) provide equity financing as shareholders of many of the smaller companies.

- Domestic governments provide investment subsidies to producers; provide equity financing as owners of companies active in feedstock and biofuel production; and provide debt financing as owners of national development banks (Kutas et al. 2007, Fenton 2009).

- Foreign governments provide foreign investment subsidies to domestic producers investing abroad and grants (development aid) to foreign producers; provide equity financing as owners of companies investing in feedstock and biofuel production abroad; and provide debt financing as owners of foreign development banks and export credit agencies (Fenton 2009).

- Banks (both domestic and foreign) provide debt financing in the form of loans; and help companies to sell shares and bonds to institutional investors.

- Institutional investors (both domestic and foreign), including pension funds, insurance companies and asset managers provide equity financing by buying shares of feedstock and biofuel producers; and provide debt financing by buying bonds of these companies.

- Multilateral financial institutions provide debt financing in the form of loans; provide equity financing by buying shares of feedstock and biofuel producers; and provide grants to companies. The World Bank and all regional development banks are active in the biofuel sector. Most active is the Inter-American Development Bank (IDB), which is assisting Argentina, Costa Rica, Colombia, the Dominican Republic, El Salvador, Guatemala, Guyana, Haiti, Honduras and Peru with the development of national biofuel development policies and providing loans to biofuel companies. In July 2008, the IDB arranged a US\$ 648 million investment in 3 new ethanol plants in south-central Brazil, by far the largest investment by any multilateral bank (Van Gelder 2009).

Based on a number of criteria (amount of capital, related risk, and others), the importance of each group of financiers (high, moderate or low) for each company. Taking into account the differences in size of the researched companies, we aggregated these assessments for each case study. Taking into account 
differences in size between the feedstock and biofuel sectors in different case studies, we then aggregated these findings for the 3 regions, for the 4 types of feedstock grown and the 4 types of biofuel produced (Table 4).

In the jatropha sector we found foreign entrepreneurs, foreign governments and foreign institutional investors to be the most important financiers. Only in India do banks (both domestic and foreign) play an important role, as domestic oil companies are moving into the sector. Domestic governments of Ghana and Mexico also play an active role, whilst foreign governments (e.g. Italy, Sweden, the Netherlands, the United States and Abu Dhabi) are important financiers in Mozambique, Tanzania and Zambia. With the exception of Ghana, the importance of multilaterals is low (Van Gelder and German 2011).

For the 2 main oil palm producers, Indonesia and Malaysia, domestic governments and entrepreneurs play a very important role. In Indonesia, the role of foreign governments and foreign entrepreneursparticularly from Malaysia-is more important than in Malaysia. Domestic and foreign banks and institutional investors are also important in both countries. In Colombia, domestic entrepreneurs are the most important in the oil palm sector, whereas in Africa foreign entrepreneurs play a significant role. In Cameroon and Colombia the domestic government is important, whereas in Congo and the DRC foreign governments such as China and Italy (via state-owned companies) are financing most plantation expansion. In the palm-based biodiesel sector, the importance of foreign governments and domestic institutional investors is relatively small and only in Indonesia do multilaterals play a fairly significant role. In financing the Brazilian soybean cultivation and soy-based biodiesel sector, the domestic development bank BNDES is very important. Most of the companies active in this sector are privately owned; therefore, domestic and foreign entrepreneurs also play a large role. To finance their expansion plans, companies attract loans from domestic and foreign banks. Some of the foreign companies also issue shares and bonds to foreign institutional investors. In Bolivia the role of foreign governments, entrepreneurs, banks and institutional investors is important (Van Gelder and German 2011).

Table 4. Importance of financial stakeholders for 20 biofuel cases

\begin{tabular}{|c|c|c|c|c|c|c|c|c|c|c|c|}
\hline \multirow[t]{2}{*}{ Group of financial stakeholders } & \multicolumn{3}{|c|}{ By region } & \multicolumn{4}{|c|}{$\begin{array}{l}\text { Cultivation of different } \\
\text { feedstocks }\end{array}$} & \multicolumn{4}{|c|}{$\begin{array}{l}\text { Biofuel production based on } \\
\text { different feedstocks }\end{array}$} \\
\hline & 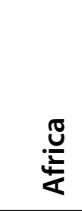 & $\frac{\pi}{4}$ & 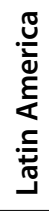 & 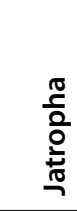 & $\begin{array}{l}\frac{\varepsilon}{\pi} \\
\frac{2}{0} \\
\overline{0}\end{array}$ & ๙ัర & $\begin{array}{l}\text { v } \\
\text { J } \\
\frac{U}{\pi} \\
\text { o } \\
\sim\end{array}$ & $\begin{array}{l}\frac{0}{c} \\
\frac{0}{0} \\
\frac{0}{0} \\
\stackrel{0}{0}\end{array}$ & $\frac{\frac{\varepsilon}{\pi}}{\frac{0}{0}}$ & ๙ั & 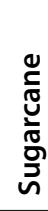 \\
\hline Number of case studies & 12 & 3 & 5 & 7 & 6 & 2 & 5 & 1 & 3 & 1 & 2 \\
\hline Domestic entrepreneurs & - & & 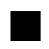 & $\mathbf{\square}$ & $\mathbf{\square}$ & $\mathbf{\square}$ & $\mathbf{\square}$ & - & $\mathbf{\square}$ & $\mathbf{\square}$ & $\mathbf{\square}$ \\
\hline Domestic government & $\mathbf{\square}$ & & 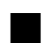 & $\mathbf{\square}$ & $\mathbf{\square}$ & $\mathbf{\square}$ & घ & $\mathbf{\square}$ & $\mathbf{\square}$ & & 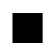 \\
\hline Domestic banks & - & & - & - & - & $\mathbf{\square}$ & - & - & $\mathbf{a}$ & $\mathbf{\square}$ & $\mathbf{a}$ \\
\hline Domestic institutional investors & - & $\mathbf{\square}$ & - & - & - & - & - & - & - & - & - \\
\hline Foreign entrepreneurs & $\mathbf{\square}$ & $\mathbf{\square}$ & $\mathbf{\square}$ & & $\mathbf{\square}$ & & - & & $\mathbf{\square}$ & $\mathbf{\square}$ & $\mathbf{\square}$ \\
\hline Foreign governments & & - & घ & & $\mathbf{\square}$ & $\mathbf{\square}$ & & & - & - & $\mathbf{\square}$ \\
\hline Foreign banks & & & घ & $\boldsymbol{\square}$ & $\square$ & $\square$ & & & घ & $\mathbf{\square}$ & $\square$ \\
\hline Foreign institutional investors & & & 口 & & $\mathbf{\square}$ & $\mathbf{\square}$ & & & $\mathbf{\square}$ & $\mathbf{\square}$ & $\mathbf{\square}$ \\
\hline Multilateral institutions & $\mathbf{a}$ & - & $\cdot$ & - & - & - & $\mathbf{\square}$ & - & - & - & घ \\
\hline
\end{tabular}

= high, $\mathbf{\square}=$ moderate, $\mathbf{~ = ~ l o w ~ ( T h i s ~ w e i g h t i n g ~ i s ~ b a s e d ~ o n ~ s e v e r a l ~ c r i t e r i a , ~ i n c l u d i n g ~ a m o u n t ~ o f ~ c a p i t a l ~ a n d ~ r e l a t e d ~ r i s k ) ~}$ 
Expansion of sugarcane production in Brazil is financed mainly by domestic entrepreneurs and the government. Companies also attract loans from domestic and foreign banks. In the 4 African countries, foreign governments play an important role, as do the foreign banks and foreign institutional investors backing the foreign companies dominating the sector. The domestic government is important in Mozambique, domestic entrepreneurs play a significant role in Zambia and domestic banks are important in Tanzania. Multilaterals play a very important role in Malawi. Because of the high integration of sugarcane and ethanol production, the sugar-based ethanol sector is mainly financed by the same stakeholders investing in sugar production for the food industry (Van Gelder and German 2011).

Taking a regional perspective, we note that in Africa the role of domestic financiers is much smaller than in the other regions. Domestic governments are less involved than in other regions, but in particular domestic banks and domestic entrepreneurs are strikingly absent. This is in sharp contrast to Asia, where these 2 groups of financiers play a very important role. Much of the feedstock and biofuel development in Africa depends on grants, loans and investments by foreign governments, foreign development banks and foreign state-owned companies. Foreign development agencies and other foreign government institutions from Abu Dhabi (in Zambia), Italy (in Mozambique), Sweden (in Mozambique, Tanzania) and the United States (in Madagascar, Tanzania) are very active with loans and technical assistance programmes. The Italian state-owned oil company ENI, for instance, is a major financier in palm oil production for biofuel in Congo. The Angolan state-owned oil company Sonangol and the Portuguese state-owned holding Parpública are jointly active in jatropha development in Mozambique.

Foreign entrepreneurs play a moderately important role in all regions. Foreign institutional investors and banks are very important in Africa and Asia, but not in Latin America where most companies are either privately or state owned. Multilateral financial institutions are significant only in a few countries (e.g. Ghana, Malawi) (Van Gelder and German 2011). 


\section{Responsible financing by private and public financiers}

\subsection{What is responsible financing?}

Responsible or sustainable financing can be described as integrating the environmental, social and governance (ESG) impacts of financial services in the financing decision-making process. In addition, the sustainability concept includes a longer-term financial dimension and an ethical dimension. The concrete meaning of sustainability for the financial sector is a controversial issue and continues to evolve (Gerster 2011).

Different groups of financiers use different terminology for what is basically the same activity. In the private banking sector it is often called Sustainable Banking (FT 2010), whereas institutional investors generally refer to Socially Responsible Investing (SRI) (Richardson 2007). To avoid any misunderstanding, in this report we assume that only production and trading companies make investments, whereas private and public financiers can finance these investments. For this reason we use the term 'responsible financing' in this report as the overall term for what is variously described as Sustainable Banking, SRI or something similar.

At the origins of the movement of public and private financiers towards responsible financing are the multilateral banks: World Bank Group, Asian Development Bank, Inter-American Development Bank and others. Since their establishment in the post-war period, these banks have integrated development objectives in their financing decisionmaking processes. Over the years, they gradually adopted more and more social and environmental principles and developed criteria to evaluate their financing decisions. This became grounded strongly in the concept of sustainability around the World Summit on Sustainable Development in Rio de Janeiro in 1992, which spurred development of a responsible financing policy by the IFC. Other multilateral development banks followed this development.

During the past 10 years, responsible financing has become more widespread in the financial sector, including amongst public financiers such as national development banks, foreign development banks and export credit agencies, and private financiers such as banks, pension funds, insurance companies, asset managers and other financial institutions (Zeller 2010, Gerster 2011). More and more financiers developed a responsible financing policy that contains the social and environmental principles and criteria with which a financial institution's investments need to comply.

These social and environmental principles and criteria usually relate to the ways in which a company (in which the financial institution is considering to invest) is managing its business, the products or services the company offers and the anticipated social and environmental consequences of the operations or products of the company and/ or its suppliers. Although similar criteria could be applied when the financial institution is dealing with individuals or states (Coulson 2009), we limit this chapter to responsible financing instruments applied to investments in companies, specifically those operating in the biofuel sector.

When an investment proposal is screened against the responsible financing policy, it can be approved, rejected or conditionally approved. The screening process could also trigger further actions for the financial institution to take towards the companies in which it is already investing or planning to invest. These actions are described in section 2.3.

\subsection{Reasons to adopt a responsible financing policy}

Whilst multilateral development banks adopted responsible financing policies because they followed logically from their mandates, other private and public financiers have more complex arguments to follow this development. In general, responsible financing policies are adopted voluntarily by many financial institutions for 4 main reasons (UNEP FI 2006). 
For ethical reasons, more and more financial institutions feel they have a responsibility to contribute to sustainable development in all their business activities. This vision is integrated in their business principles, which guide their operations (UNEP FI 2010, UNPRI 2010).

Increasing attention of non-governmental organisations (NGOs) and media on the impacts of financial institutions' investments has increased their reputational risks. To avoid damage to their reputation in the marketplace, which is of crucial importance to most financial institutions, many realise they have to avoid investments that are publicly perceived as irresponsible (Scholtens 2006).

Taking sustainability risks into account can improve the bank's understanding of its financial risks and its capacity to deal with these risks. Not so much because of juridical liability. The UK, where a secured lender, executing a charge and taking possession of the land, may, since 2003 , be liable under the Environmental Protection Act for cleaning up contaminated land (McDermott $e$ t al. 2005), is an exceptional case. More important than liability risks is the probability that the avoidance of environment-related and social risks can reduce the client's reputational risk and its exposure to claims for damages. This will have a positive effect on the company's financial performance and the financial risk profile of the financier: 'Sustainability criteria can be used to predict the financial performance of a debtor and improve the predictive validity of the credit rating process. We conclude that the sustainability a firm demonstrates influences its creditworthiness as part of its financial performance' (Weber et al. 2010, p. 39).

Companies which perform well on social and environmental issues often yield financiers more financial returns, for various reasons: 'For instance, a credible corporate social responsibility (CSR) strategy can have a positive influence on employee loyalty or strengthen the company's positive reputation in the marketplace' (Schmidt and Weistroffer 2010, p. 10). A recent study by the consultancy firm Mercer, which reviewed 36 scientific studies examining the relationship between responsible financing instruments and the financial performance of asset managers, concluded that 20 studies found a positive relationship and only 3 studies showed evidence of a negative relationship (Mercer 2009).

\subsection{Responsible financing instruments}

A responsible financing policy contains the social and environmental principles and criteria with which the investments of a financial institution need to comply. Although various types of private and public financial institutions can use the same responsible financing policy, the specifics of their activities require differences in instruments to apply the responsible financing policy in their decision-making processes. Broadly speaking, 4 groups of financial institutions can be distinguished, each with its own approach to responsible financing: multilateral banks, other public financiers, private banks and institutional investors. The different approaches and the responsible financing instruments they apply are summarised in the following paragraphs.

\subsubsection{Multilateral development banks}

All multilateral development banks now have a system in place to evaluate whether investments meet the social and environmental criteria of the bank, as defined in their responsible financing policies. The screening process is well developed and can include field visits, Environmental Impact Assessments (EIAs) and Human Rights Impact Assessments (HRIAs).

All multilateral banks have formulated general social and environmental criteria which are also applicable to feedstock and biofuel investments, and some have developed specific criteria for the biofuel sector (Van Gelder 2009). Notable examples in this respect are the IDB Biofuels Sustainability Scorecard by the IDB, which is very active in the biofuel sector via its Sustainable Energy and Climate Change Initiative (SECCI) programme, and the Performance Standards of the IFC. These address a wide range of social and environmental risks, such as protection of human rights, protection and conservation of biodiversity, use and management of dangerous substances, impacts on affected communities and indigenous peoples, labour rights, pollution prevention and waste minimisation (see Box 2).

\subsubsection{Other public financiers}

Various public financiers other than multilateral development banks are involved in feedstock and biofuel production (see paragraph 1.7.2). Some of these public financiers are owned by the governments of the countries where the investments take place, others are owned by foreign governments. 


\section{Box 2. Multilateral development bank criteria relevant for biofuels}

\section{IDB Biofuels Sustainability Scorecard}

To ensure that its biofuel investments contribute to sustainable development, the Inter-American Development Bank (IDB) has initiated a partnership with the Roundtable on Sustainable Biofuels to integrate the Roundtable's sustainability principles into its lending policies, and to test these principles in projects that it supports. The resulting IDB Biofuels Sustainability Scorecard aims to 'encourage higher levels of sustainability in biofuels projects by providing a tool to think through the range of complex issues associated with biofuels' (IDB 2010).

In September 2009, the IDB released a new version of the IDB Biofuels Sustainability Scorecard. The first version of the scorecard, released in 2008, addressed 23 key variables including greenhouse gas emissions, water management and biodiversity. The updated version includes new categories to capture more thoroughly the environmental and social dimensions of biofuels investments. Specifically, there are 6 new categories that address issues relating to indigenous people, local grower arrangements and impact on food security, amongst others (IDB 2009a).

The IDB Biofuels Sustainability Scorecard asks questions about proposed projects and assigns points to each answer. Issues covered include the conservation value of the project site and the impact of direct land use change on greenhouse gas emissions. The Scorecard also seeks to address emissions from indirect land use change by assigning more points to the use of degraded lands and discouraging the use of forest land. Another category concerned with biodiversity loss includes the extent to which field burning is used as a harvesting method (IDB 2009b).

\section{Performance Standards of the IFC's sustainability policy}

The sustainability policy of the International Finance Corporation (IFC, the private sector subsidiary of the World Bank) includes 8 performance standards that define clients' roles and responsibilities for managing their projects and the requirements for receiving and retaining IFC support. The IFC applies the standards to manage social and environmental risks and impacts and to enhance development opportunities in its private sector financing (IFC 2006a).

Standard 6 addresses the issue of 'biodiversity conservation and sustainable natural resource management'. This standard reflects the objectives of the Convention on Biological Diversity and addresses how clients can avoid or mitigate threats to biodiversity arising from their operations as well as sustainably manage natural resources. The requirements for IFC support set in this standard include rules of behaviour in natural, modified and critical habitats and legally protected areas; for the introduction of invasive alien species; and for operations in freshwater and marine systems.

With regard to deforestation, one requirement is specifically important (IFC 2006b, IFC 2010a):'Forests are in particular principal providers of natural resources and therefore need to be managed in a sustainable manner. This includes that:

- clients involved in natural forest harvesting or plantation development cannot cause any conversion or degradation of critical habitat or areas defined as High Conservation Value (HCV);

- where possible, the client has to locate plantation projects on unforested land or land already converted (not in preparation for the project); and

- the client has to ensure that all natural forests and plantations under its management are 'independently certified' as meeting performance standards compatible with internationally accepted principles and criteria for sustainable forest management.'

Note: The IFC has not provided a definition of 'independently certified'.

In some cases, these public financiers use responsible financing policies to tie social and environmental conditions to their investments, but adoption and implementation of responsible financing policies differ between groups of public financiers. Following is a brief overview of the experiences of public financiers with responsible financing policies and instruments. 
Investment subsidies for domestic feedstock and biofuel production. In some countries, conditionalities on government subsidies are geared towards enhancing the social and environmental sustainability of biofuel production. For instance, following food security concerns resulting from the expansion of food-based biofuels (e.g. maize and wheat) in China, policies have been developed to encourage the production of biofuels from non-grain feedstocks grown on marginal land identified as suitable for these crops (GSI 2008). However, further investigation is needed to determine how widespread is the use of considering social and environmental conditions in domestic feedstock and biofuel production. An encouraging development in this respect is the Global Bioenergy Partnership (Box 3), which could lead to the governments involved adopting clear criteria.

\section{Development financing and foreign investment}

loans. Some bilateral development institutions commit to using the same criteria as the multilateral development banks. The Dutch development bank FMO, for instance, is a signatory to the Equator Principles (Equator Principles 2010b). However, many other governmental institutions involved in financing foreign trade and investments do not set similar social and environmental criteria. NGOs are calling upon governments in the EU to attach the same criteria to these forms of public financing as for biofuel imports (Kutas et al. 2007, Fenton 2009)

Export credit loans and guarantees. In December 2003, the Working Party on Export Credit and Credit Guarantees of the Organisation for Economic Co-operation and Development (OECD), of which most export credit agencies (ECAs) are members, published a 'Recommendation on Common Approaches on Environment and Officially Supported Export Credits'. In this document, the Working Party recommends a number of 'common approaches for identifying and evaluating the environmental impacts of projects'. Although none of these approaches directly refers to deforestation, the document does list some examples of sensitive sectors and areas, including 'forests with high biodiversity value'. Common approaches are derived in large part from World Bank procedures and are oriented towards 'sensitive sectors', including 'largescale primary agriculture/silviculture involving intensification or conversion of natural habitats' (OECD 2003). Several NGOs, collaborating in ECA Watch, claim that the 'Common Approaches' agreement has too many loopholes. They point for example to a statement that 'ECA-backed projects should "in all cases" comply with World

\section{Box 3. Global Bioenergy Partnership}

In the Gleneagles Plan of Action, the G8 leaders agreed to launch a Global Bioenergy Partnership (GBEP), based on an Italian initiative, to mitigate fossil fuel dependency and greenhouse gas emissions. The GBEP is a commitment of all G8 countries, along with China, Mexico, the Food and Agriculture Organization of the UN (FAO), the International Energy Agency (IEA) and the European Biomass Industry Association (EUBIA) to promote the development and commercialisation of renewable energy by supporting wider, cost-effective biomass and biofuel deployment, particularly in developing countries. The aim is to increase and facilitate exchanges of experiences and technologies not only North-South, but also South-South and South-North (GBEP 2006).

The GBEP, launched in May 2006, now mainly provides a mechanism for partners to organise, coordinate and implement targeted international research, development, demonstration and commercial activities related to production, delivery, conversion and use of biomass for energy. GBEP also provides a forum to develop effective policy frameworks to suggest rules and tools to promote sustainable biomass and bioenergy development; facilitate investments in bioenergy; promote project development and implementation; and foster R\&D and commercial bioenergy activities (GBEP 2010).

By the end of 2010, the GBEP had developed and tested a common methodological framework for use in measuring and reporting greenhouse gas emissions reductions from bioenergy and is continuing work on developing a set of global, voluntary, science-based criteria and indicators regarding the sustainability of bioenergy. GBEP has also published on its website collations of financing options and analytical tools currently available, the latter developed in collaboration with UNEP and FAO. GBEP intends to initiate work in 2011 on facilitating capacity building for sustainable bioenergy (GBEP 2011). 
Bank, regional development bank and host country standards, unless an ECA "finds it necessary" to apply lower standards'. They also highlight the lack of adequate environmental and social policies and associated professional staff to perform due diligence, and claim that this results in projects that contravene international environmental, human rights and other treaties and agreements to which the ECAs' own governments are parties (ECA-Watch 2010).

\section{Investments by state-owned companies. State-}

owned companies were often found to be involved in financing feedstock and biofuel investments, both in their own country and abroad (see paragraph 1.7.2). Which social and environmental conditions are tied to investments by state-owned companies is largely determined by their corporate social responsibility (CSR) policies. No clear examples of CSR policies for the biofuel sector were found, although the Global Bioenergy Partnership (Box 3) might be expected to motivate state-owned companies to develop these.

\subsubsection{Private banks}

Private banks provide loans and other credit to companies (commercial banks), help companies issue shares and bonds or advise them on mergers and acquisitions (investment banks). Typically, in requesting this kind of financial service, the company opens a dialogue with the bank. During this dialogue, the bank visits the company's operations and reviews its financial administration and other confidential information. This due diligence process aims to assess whether the company meets the banks' financial criteria and under which (financial) conditions the bank is prepared to offer its services

When a responsible financing policy is adopted, this due diligence procedure needs to be broadened to assess whether the investment proposal also meets the bank's social and environmental criteria. This screening can be undertaken by the same relationship manager that undertakes the financial due diligence, or by a specialised department (such as the risk management department). It can include questionnaires, literature review, conversations with NGOs, field visits and, if necessary, an assessment by an external consultant. As their due diligence process gives them access to confidential company information, banks have an advantage over institutional investors (see paragraph 2.3.4) in assessing whether a company meets its social and environmental criteria. This confidentiality also has its drawbacks, however, as it prevents banks from making public which companies they have declined to finance out of fear of losing market share by breaching the confidential relationship with their customers.

An investment proposal that fails to meet the criteria set in the bank's responsible financing policy may be directly rejected. Alternatively, a dialogue process may follow that results in a plan to implement certain changes in the operations of the company or an agreement that the investment cannot be used for certain activities the company undertakes. Based on this agreement and under the condition that the company acts in accordance with the agreement, the financial institution can decide whether to continue with the proposed investment. In loan contracts, these conditions can be formalised in covenants of the contract (Van Gelder and Taylor 2008).

\subsubsection{Institutional investors}

Institutional investors include asset managers, pension funds, insurance companies and other investment companies. In contrast with banks, institutional investors do not provide loans to companies. However, they do provide finance to companies through such forms of investment as shares, corporate bonds, private equity and real estate. In particular, shares and bonds are standardised investment objects, traded rather anonymously on the capital market. This means that the investment process does not normally require a dialogue between investor and company, as is the case with bank investments (see paragraph 2.3.3). As part of the investment decision process, institutional investors do not normally have access to confidential company information.

Apart from these differences, the responsible financing decision processes of banks and institutional investors are comparable. The institutional investor first defines an investment universe in which it wants to invest (based on geographical and sectoral boundaries) and then screens all listed companies in this universe to assess whether they meet the criteria in its responsible financing policy. This screening can be done inhouse or can be outsourced to an external asset 
manager. The information used can be obtained from the companies directly, through publications, questionnaires and interviews, or from ethical rating agencies, media, NGOs and other sources. The following 3 types of screening can be discerned (UNEPFI 2005, Giamporcaro et al. 2010).

Passive screening. Passive screening refers to making investment decisions by following share indices that are based upon social and environmental criteria, such as the Dow Jones Sustainability Index and the FTSE4 Good.

Positive screening. Positive screening involves setting inclusive criteria that must be met before an investment is included within a portfolio, such as strong employee relations or superior environmental performance. The best-known form of positive screening is selecting the companies that are 'best in class' in their industry.

Negative screening. Negative screening involves applying social and environmental criteria to exclude companies from the investment universe because of the products or services they offer (e.g. alcohol, weapons, nuclear energy) or the way in which they operate (e.g. involvement in serious human rights infringements or structural deforestation). The investor puts such companies on its exclusion list (see Box 4).

Institutional investors can use a combination of different types of screening and can complement the screening process with other responsible financing instruments, for which the screening process often provides input. The 2 most important instruments are voting on shareholder meetings and engagement (Gootjes and Herder 2009, Giamporcaro et al. 2010).

Voting on shareholder meetings. Institutional investors that own shares in a company are co-owners of that company. By voting on shareholder resolutions (which they may have drafted themselves), they can steer the company's management in a more sustainable direction.

Engagement. Institutional investors can start discussions behind closed doors with the companies in whose shares and bonds they invest, to influence the behaviour of these companies.

\section{Box 4. Exclusion list of the Norwegian Government Pension Fund}

The Norwegian Government Pension Fund is the largest pension fund in the world and has a very active responsible investment policy. It has an independent Council on Ethics which advises on the companies to be placed on its exclusion list. At present its exclusion list includes 45 companies, which are excluded because they are involved in (NGPF 2011):

- the production of weapons that through their normal use may violate fundamental humanitarian principles (land mines, cluster munitions, nuclear arms);

- sale of weapons and military material to Burma;

- production of tobacco;

- actions with an unacceptable risk of contributing to serious or systematic human rights violations or severe environmental damage;

- other particularly serious violations of fundamental ethical norms; or

- serious violations of the rights of individuals in situations of war and conflict.

A few companies have been excluded because of their involvement in deforestation. The clearest example is the Malaysian forestry company Samling, which was added to the exclusion list in August 2010 because its 'forest operations in the rainforests of Sarawak and Guyana contribute to illegal logging and severe environmental damage' (NGPF 2010). In addition, the Russian mining company Norilsk Nickel is on the exclusion list because the Council on Ethics 'finds that the emissions from the company are the direct cause of forest death and other serious, visible damage to the natural environment' (NGPF 2009).

Other pension funds have similar exclusion lists, which mostly focus on investments in the weapons industry and (sometimes) on gross human rights violations. Environmental or biodiversity issues are seldom a reason to put a company on an exclusion list. 
Often, engagement is collectively undertaken by a group of institutional investors. They can undertake the engagement themselves, or hire a specialised company-an engagement service provider-to hold discussions with companies on behalf of the institutional investors. To prevent such discussions from continuing endlessly without result, institutional investors can decide to put a company on its exclusion list if the engagement has not yielded any result after a number of years (Novethic 2011).

\subsection{Types of responsible financing policies}

At the core of a financial institution's responsible financing strategy is its responsible financing policy-a clear responsible financing policy gives guidance on how and where the institution can apply responsible financing instruments. In practice, the responsible financing policies of various financial institutions differ in their ability to play this guiding role. The following paragraphs divide responsible financing policies in 3 groups. First, a distinction is made between intentional statements - which show the goodwill of a financial institution but do not include well-defined criteriaand real responsible financing policies that do include these criteria. Subsequently, within the group of responsible financing policies, a distinction is made between collective and individual policies.

\subsubsection{Intentional statements}

Although often mistaken for actual responsible financing policies, intentional statements made by financial institutions on this topic often do no more than express the intention to apply responsible financing policies to (some of) their investment decisions. When - or if - this intention will lead to the actual adoption and implementation of responsible financing policies is often uncertain.

Two types of intentional statements can be discerned: single-institution and collective intentional statements. In single-institution statements, available on many financial institutions' websites or in their annual reports, the institution promises that its investments will 'contribute to a more sustainable world' or something similar. Collective statements are more formalised and are undersigned by a number of financial institutions that promise to 'take into account' or 'integrate' social and environmental criteria in their investment decision-making processes. Examples of these collective statements are the UNEP FI Statements and the UN Principles for Responsible Investment (see Box 5).

If such intentional statements are not followed within a reasonable period of time by the development and implementation of actual responsible financing policies, they become meaningless. If a financial institution states that it will only make investments which are 'good for the environment', this statement can never be falsified as long as the financial institution does not define what it means by 'good for the environment'. Intentional statements can then therefore easily result in greenwashing the operations of the financial institution (BankTrack 2005).

This danger is recognised by the initiators of these statements. For instance, in March 2005, the new UNEP FI chairman announced that UNEP FI would 'part company with those institutions that do not pay their requisite fees or abide by the statements they originally signed up to. This is important if the UNEP FI brand is not to be undermined' (BankTrack 2005); since that statement, the number of UNEP FI signatories more than halved.

Box 5. Examples of collective intentional statements

\section{UNEP FI Statements}

The Finance Initiative of the United Nations Environment Programme (UNEP FI) is an initiative to develop, promote and understand the linkages between the environment, sustainability and financial performance with a view to promoting socially and environmentally responsible investment. The UNEP FI currently has nearly 200 signatories to 1 of the 2 UNEP FI Statements, including banks, insurance companies and fund managers (UNEP FI 2010).

\section{UN Principles for Responsible Investment (PRI)} The Principles for Responsible Investment (PRI) is an initiative between investors, the UNEP Finance Initiative and the UN Global Compact. It is a framework in the form of investment principles that can be used for incorporating environmental, social and corporate governance (ESG) issues into mainstream investment decision-making and ownership practices. PRI currently has 769 signatories, amongst which are 417 investment managers, 207 asset owners (such as pension funds) and 145 professional service partners (UNPRI 2010). 


\subsubsection{Collective responsible financing policies}

Responsible financing policies need to contain well-defined, verifiable criteria which the financial institution can use to evaluate the proposed investment. Preferably, these criteria are derived from internationally recognised standards. Many financial institutions have set up their own benchmarks which meet these criteria, but there are also collective responsible financing policies undersigned by a group of financial institutions.

The most important and best-known collective responsible financing policy is the Equator Principles. The set of Equator Principles is a financial industry benchmark for determining, assessing and managing social and environmental risk in project financing. Signatories to the Equator Principles commit to adhere to the environmental and social guidelines ('Performance Standards') of the IFC when providing project finance or related advisory services for projects costing US\$ 10 million or more. Currently 67 financial institutions have adopted the Equator Principles (Equator Principles 2010b).

\subsubsection{Single-institution responsible financing policies}

During the past 10 years, more and more financial institutions have developed their own responsible financing policies for various sectors and sustainability issues (Perez 2007). Leading this development was the World Bank Group. Its privatesector subsidiary, the IFC, has more than 2 decades of experience with assessing investment proposals against its Performance Standards, which define criteria on a broad range of social and environmental issues. Other public banks have followed this trend (see paragraph 2.3.1).

During the same period, more and more private financial institutions have begun to follow the lead of (multilateral) public banks, either by undersigning the Equator Principles or by developing their own benchmarks. In a study on the sustainability policies of 49 large international banks published in April 2010, the NGO network BankTrack concluded that many banks now have publicly available policies in place. Only 6 banks out of the 49 studied were found to lack policies for the 7 sectors and 9 issues evaluated. However, the study concluded that the overall quality of investment policies developed by these banks is fairly poor. The content of many policies is vague, does not express any firm commitment and usually fails to meet best international standards. Furthermore, implementation of these policies in the decisionmaking processes of the banks is rarely complete or stringent.

As the issues and sectors for which banks have developed policies or benchmarks vary, the number of banks which have developed benchmarks relevant to the biofuel sector is more limited. Of the 49 banks covered in the BankTrack study, 16 had developed a forest(ry) policy and 9 had developed an agricultural policy (Van Gelder et al. 2010). A specific biofuel policy has been developed by only a handful of private financial institutions, including Rabobank (the Netherlands) and Standard Chartered (UK) (see Box 6).

\subsection{Effectiveness of responsible financing policies}

\subsubsection{Methodological difficulties}

Making a reliable evaluation of the effectiveness of public and private financiers' responsible financing policies in leveraging more sustainability in biofuel investments requires the following: a list of the feedstock and biofuel companies in which they have decided to invest since adopting a responsible financing policy and a list of biofuel companies they decided not to finance (accompanied by the reason of rejection).

Feedstock and biofuel companies financed. More and more institutional investors, especially pension funds, publish lists of the companies they have financed, which makes it possible to check whether these companies are indeed meeting the social and environmental conditions set in their responsible financing policies. All multilateral banks and many export credit agencies do the same.

Many institutional investors do not publish this information, however, and almost no private bank publishes it comprehensively. Information on each bank's financings in the biofuel sector is therefore limited to the larger deals, in which more banks 


\section{Box 6. Examples of single bank responsible financing policies}

\section{Rabobank policy}

Rabobank's Biofuels Policy states that the bank wants to 'contribute to the realisation of a sustainable biofuels supply chain by client assessment and client engagement'. Specifically, Rabobank has formulated the following 'conditions for investments' for upstream and downstream companies in the biofuel sector. They must:

- show the legality of their operations and comply with all applicable local, national and international ratified laws and regulations;

- have in place a policy that guarantees that the feedstock used comes from a company that adheres to the conditions described in Rabobank's Palm Oil, Sugarcane, Soy and Forestry Supply Chain Policies;

- not produce biofuels or other bioliquids that contain raw material obtained from land with high carbon stock;

- produce biofuels that provide clear GHG benefits after considering the entire lifecycle of raw material from cultivation, production and use compared with fossil fuel;

- ensure to their best ability that the biomass used for the biofuels does not replace (land for) staple crops when there are indications of local food insecurity;

- work in accordance with the human rights guidelines as described in the human rights policy of the Rabobank. Group (Rabobank 2010)

\section{Standard Chartered policy}

Standard Chartered's policy states that it is concerned about 'the unintended environmental, social and economic consequences of inefficient biofuels and unsustainable industry practices'. Therefore, the bank will evaluate financing requests from biofuel producers, against the following criteria:

- impact on food prices and food security, directly by reducing food supply or indirectly through land use change;

- energy and GHG emissions savings; and

- potential for deforestation.

According to these criteria, the bank will suspend financing to new first-generation production facilities that use corn or wheat as feedstock for ethanol production. The bank will also support the use of palm oil as feedstock only where it is produced sustainably (SCB 2010).

are involved; such deals are often published in the financial press and in financial databases such as Thomson and Bloomberg.

\section{Feedstock and biofuel companies not financed.}

Even fewer financial institutions make available information on the other side-the biofuel companies that a financial institution decided not to finance, including the reasons for this rejection. Institutional investors increasingly publish exclusion lists (see Box 4), but multilateral banks, ECAs and private banks generally do not identify companies they refuse to finance, nor the reasons for which their proposals are rejected. Private banks adopt this stance because of the confidential relationship they have with their clients (see paragraph 2.3.3), which they do not want to breach for commercial reasons. Although it is plausible that financial institutions that have adopted a responsible financing policy sometimes do decline finance to certain companies because they would cause deforestation, there is almost no empirical evidence available to support this assumption.

Signatories to the Equator Principles have taken the first step in this regard, having recently started to report on the numbers of projects that they refused to finance. However, as explained in paragraph 2.4.2, the project finance market is a niche market that has little relevance for biofuel investments. In addition, the information provided is fairly limited. The banks publish only whether or not the project was deemed to conform with the Equator Principles, into which Equator Principle category it falls, if the project is located inside or outside OECD countries, and to which sector the project belongs. The name of the project and the reasons for rejection are not reported (Equator Principles 2010b).

In several known cases, such as the example given in Box 8, in which a bank or other financier 
declined to finance a certain project or company for environmental reasons (including feared deforestation), the refusal occurred only after the financial institution was put under pressure by NGOs. Such cases provide an indication of the actual effectiveness of banks' responsible financing policy in ensuring it withholds finance from companies that do not meet its social and environmental criteria; apparently, in these cases, the bank's own responsible financing instruments (such as interactions with the company, reviews) led to a positive (draft) decision to finance the company, but this decision was reversed following NGO pressure.

As long as most banks and other financial institutions continue not to publish information on which companies in the biofuel sector they do and do not decide to finance, it will remain impossible to make an empirical evaluation of the effectiveness of their responsible financing policies. The following assessment is therefore based mainly on theoretical considerations and circumstantial evidence.

\subsubsection{Evaluation of effectiveness}

In this paragraph, we use the following 5 criteria to evaluate the effectiveness of responsible financing policies in the financial sector in leveraging sustainable investments in the biofuel sector.

1. Are the criteria in the responsible financing policy defined in a clear and measurable way?

2. Are the criteria in the responsible financing policy based on internationally agreed conventions or standards defined by multi-stakeholder initiatives?

3. Are independent and strong monitoring and accountability mechanisms set up to strengthen implementation?

4. How is the scope or reach of the responsible financing policies defined?

5. How likely is the responsible financing policy to have an impact on sustainable investments in the biofuel sector, taking into account the previous criteria?

The findings of our evaluation are summarised below.

\section{Criterion 1: Are criteria defined in a clear and measurable way?}

The policies of multilateral development banks usually include defined and measurable indicators. This is certainly the case for the Performance Standards of the IFC (see Box 2), which are detailed and clear about what is acceptable and what is not. The criteria included in the Biofuels Sustainability Scorecard of the IDB (Box 2) are also fairly detailed; however, the scorecard model allows unacceptable practices in one field to be compensated for by acceptable practices in other fields.

Insofar as bilateral development agencies, investment banks and export credit agencies take their lead from the policies of multilateral banks, especially the World Bank, their policies would have the same level of detail and measurability. There are clear doubts, however, as to whether many of these public financiers are indeed applying the same conditions as the multilateral banks. For example, a study on financing by European ECAs of forest-related infrastructure and pulp and paper projects in the past 15 years, including a number of controversial expansion projects in Indonesia, concludes that 'this support was, and continues to be "blind", not taking environmental or social issues into account or investigating whether operators' prospectus documents were based on realistic assessments of the nature or ownership of the forest resource' (FERN 2008, p.5).

For a responsible financing policy to be effective in guiding the investment decisions of financial institutions, it needs to contain well-defined, verifiable criteria that the financial institution can use to evaluate the proposed investment. It should be reasonably clear for all parties involved - the employees of the financial institution, the company that is seeking investment and possible third parties - when the investment meets, or does not meet, the criteria. For example, to avoid deforestation and channel biofuel investments to already degraded land, the responsible financing policy should include clear criteria on avoided deforestation, biodiversity and GHG emissions related to land cover change. Social criteria related to land rights and prior and informed consent should also be included.

The intentional statements discussed in paragraph 2.4.1 lack well-defined criteria. The most important collective responsible financing policy used in the financial sector-the Equator Principles-is based on the detailed and elaborate Performance Standards of 
the IFC. However, the Equator Principles have little relevance for investments in the biofuel sector.

More relevant are the responsible financing policies developed by individual financial institutions, whose levels of detail and measurability vary considerably. Only a few banks have developed responsible financing policies on biofuels or other related sectors or issues that are based on well-defined, verifiable criteria (Van Gelder et al. 2010). Two examples are presented in Box 6. However, although these policies are more elaborate than those of many other banks, they still leave some aspects open for interpretation. For example, it is not clear what the Rabobank defines as 'land with high carbon stock'. Furthermore, its statement about the replacements of food crops is unclear. The bank does not define what it means by 'when there are indications of local food insecurity'. Stating prerequisites in such a general way leaves the policy open to interpretation, both by the bank's employees and by its clients.

\section{Criterion 2: Are the criteria derived from international standards?}

A responsible financing policy derives credibility by using criteria based on internationally accepted standards. These can be standards derived from well-documented best practices in an industry, criteria defined in certification schemes or other multi-stakeholder initiatives, or criteria derived from international (e.g., UN, ILO) treaties. When the responsible financing criteria are derived from such international standards, it is clearer for all parties what the criteria entail, thus strengthening the criteria — and the responsible financing procedure as a whole (Van Gelder and Herder 2010).

The Performance Standards of the IFC point to 'internationally accepted principles and criteria for sustainable forest management', without specifying specific certification schemes. The criteria included in Biofuels Sustainability Scorecard of the IDB are developed in cooperation with the Roundtable on Sustainable Biofuels (Box 7). Other public financiers follow World Bank/IFC policies.

For feedstock and biofuel production, the criteria in the responsible financing policies of financial institutions could be based on the standards developed by multi-stakeholder initiatives (e.g. the Forest Stewardship Council (FSC), the

\section{Box 7. Roundtable on Sustainable Biofuels (RSB)}

The RSB's certification scheme for biofuel production and processing is almost ready to be implemented. This certification system aims to provide a comprehensive scheme for verifying compliance with the RSB standards for responsibly produced, processed and traded biomass/biofuels (RSB 2010a). By November 2010, the RSB had completed and approved Version 2 of the standards, which now include practicalities and related tools and guidelines.

One of these tools in a screening tool, which is part of the Impact Assessment Process that all participating operators are required to carry out. This screening process enables the participants to determine the extent and scope of the environmental and social impact assessment and helps to establish whether any specialised impact assessments are required. Supporting the screening exercise is a tool developed by the RSB that guides participants and assists them in their analysis of the potential socio-ecological impacts of their biofuel operations (RSB 2011a).

When the screening indicates an in-depth assessment is required, a full Environmental and Social Impact Assessment (ESIA) can be undertaken (RSB 2010b). The certification scheme is ready for implementation, following its launch at the World Biofuels Market in Rotterdam in March 2011 (RSB 2011b).

Roundtable on Sustainable Palm Oil (RSPO), the Roundtable on Sustainable Biofuels (Box 7) and the Round Table on Responsible Soy (RTRS)) and in international forums, such as the Global Bioenergy Partnership (Box 3).

Responsible financing policies can draw on such standards either by copying individual criteria or by referring to the standard as a whole. In the first method, the financial institution has to assess whether the proposed investment meets all the individual criteria, which can require a fairly labourintensive assessment process. In the second case, the financial institution can rely on the verification or certification process of the standard itself. For instance, if a bank states that it wants to lend to companies in the forestry sector only if they are FSC certified, its assessment procedure will be very simple and efficient, as will monitoring and 
compliance. However, this precludes the bank from doing business with clients that meet FSC criteria, but are not FSC certified. Despite the advantages, many financial institutions may prefer not to commit fully to the FSC standard for commercial reasons, and referring to such a standard in the bank's responsible financing policy is possible only for sectors in which an externally monitored certification process is in place.

\section{Criterion 3: Are independent and strong monitoring and accountability mechanisms set up to strengthen implementation?}

Since the World Bank Inspection Panel was set up in 1993, all multilateral banks have developed monitoring, compliance and accountability mechanisms. These include independent complaint mechanisms, mediation procedures, compliance mechanisms and access to decision makers for people harmed or potentially harmed by projects financed by their institutions. Although much can be improved in how these mechanisms function, they can strengthen the implementation of responsible financing policies and correct errors made (Van Putten 2008, Bissell and Nanwani 2009). The recent case of the IFC and Wilmar International provides one notable example (see Box 8).

The private financial sector has not yet followed multilateral financial institutions in creating the mechanisms listed above (Van Putten 2008,
Van Gelder et al. 2010). This is true also for the collective responsible financing policies in which private banks participate, such as the Equator Principles: 'A perceived lack of accountability at an institutional, organisational and individual project level is identified as a central reason for [the] reduction in legitimacy' of the Equator Principles (O'Sullivan and O'Dwyer 2009). This is mainly because these collective policies are voluntary and pay little attention to the creation of accountability mechanisms (Bridgeman and Hunter 2008).

Following considerable NGO criticism on this issue, the banks undersigning the Equator Principles set up an association and in July 2010 announced their governance rules. The rules define the obligations of the banks undersigning the Equator Principles, of which the main ones pay an annual fee and report annually on implementation (Equator Principles 2010a). According to BankTrack, these new governance rules may improve cooperation and decision making amongst Equator Principles financial institutions, but fall short in producing new commitments on transparency and external accountability (BankTrack 2010a).

\section{Criterion 4: How is the scope or reach defined?}

Two elements define the scope or reach of the responsible financing policies of private and public financiers: the extent to which the responsible financing policy is applied to all forms of financing

\section{Box 8. IFC and Wilmar International}

After the Forest Peoples Programme, Sawit Watch and other NGOs filed a complaint over the social and environmental impacts of IFC finance to Singaporean company Wilmar International, the Office of the Compliance Advisor/Ombudsman (CAO) for the International Finance Corporation (IFC) - the private sector arm of the World Bank-started to investigate a series of IFC loans to Wilmar. Wilmar is the largest palm oil trader in the world and the owner of significant plantations in Indonesia. NGOs alleged that although the loans were for trading facilities, they helped Wilmar expand its Indonesian plantations, which often resulted in biodiversity loss and conflicts with local communities. In June 2009 the CAO concluded that the IFC'did not meet the intent or requirements of its own Performance Standards for its assessment' of Wilmar loans (CAO 2009). In September 2009, the IFC management responded by acknowledging 'a weakness in the current Environmental and Social Review Procedures', by suspending investments in the oil palm sector and by starting a broad consultation process to improve the review procedures for investments in the oil palm sector (IFC 2010b).

At the end of February 2011, the IFC announced that it had completed the 30-day final stakeholder comment period on the revised draft 'World Bank Group Framework and IFC Strategy for Engagement in the Palm Oil Sector'. This revised draft incorporates and responds to earlier comments from a broad range of stakeholders that were provided during the consultation process. This consultation process was planned to conclude in March 2011 (IFC 2011). As it is still unclear when-or if-the IFC will lift its suspension of investments in the oil palm sector, it remains to be seen how this process will shape IFC policies and practices. 
and the extent to which it is applied to all types of companies active in the biofuel sector.

Although public financiers are important in financing feedstock and biofuel production in forestrich countries in Asia, Africa and Latin America, not all public financiers seem to have developed and implemented responsible financing policies adequately (see paragraph 2.3.2). For export credit agencies, for instance, a FERN study concluded: 'no ECAs have the relevant procedures in place to identify and address the flawed operating and expansion model that much of the pulp and paper sector has followed. What's more, by aiming for very low transaction costs, most ECAs have little internal capacity for assessing the environmental or social impacts of the operations they help to finance' (FERN 2008, pp. 5-6).

In the case of private financiers, the extent to which the responsible financing policy is applied to all forms of financing is very important. Singleinstitution responsible financing policies are generally applied to all financial services offered by the financial institution, with the exception of asset management services on behalf of third parties (i.e. private banking and management of investment funds). Most financial institutions take the view that their clients-rather than the financial institution itself-are responsible for these types of investments.

Private financial institutions do generally take responsibility for loans, credits, underwriting and investments in shares and bonds that are financed by their own funds (i.e. funds attracted from its shareholders, accountholders and policyholders and funds borrowed from other banks). These categories include a large part of the financings by banks and other private financial institutions in the biofuel sector.

However, the scope of the only relevant collective responsible financing policy, the Equator Principles, is much more limited as it is confined to project finance for projects with a value of more than US\$ 10 million. A project finance loan provides finance to part of the investments needed for a specific project: a mine, pipeline, plant, road, etc. In contrast to other loans, the repayment of a project finance loan depends only on the revenues that a project is expected to generate once it is up and running.
Banks run a fairly high risk with this form of loan: if the project is not successful and does not generate (sufficient) revenues, they will not receive interest and repayments (or less than agreed). Therefore, banks will carefully evaluate the project in advance and will demand close involvement in the day-to-day running of the project, which is not the case with other types of loans. From this perspective, it is understandable that banks have limited the Equator Principles to project finance only, but this choice severely limits the principles' scope in the biofuel market (and other markets).

Although the signatories to the Equator Principles represent more than $90 \%$ of the global project finance market, project finance itself is a niche market within the wider financial market, accounting for no more than $2 \%$ of the total corporate financing market (Thomson 2010). For some sectors such as infrastructure, oil and gas and electricity, project finance is a fairly important source of financing, especially in countries with a higher country risk. For other sectors, such as agriculture (including growing biofuel feedstocks), project finance is not at all important as a source of finance (BankTrack 2004). Some companies developing biofuel processing plants might consider attracting project finance, but in general the biofuel sector has many other financing opportunities outside the project finance marketoffered by the Equator Principles signatories as well as other financial institutions - which are not covered by the Equator Principles.

The second element that defines the scope of responsible financing instruments is the extent to which they are applied to all types of companies active in the biofuel sector. If, for instance, a responsible financing policy were to demand RSPO certification as a precondition for investments in the palm oil sector, this would only be applicable to existing plantations and traders-not to new plantations. This is because the RSPO certification scheme certifies the palm oil and not the palm oil producer. NGOs such as Greenpeace fear that some companies will develop a few model plantations to obtain the RSPO certificate, whilst continuing to operate and develop unsustainable plantations elsewhere and selling oil produced in these plantations as RSPO certified (Greenpeace 2008). As financial institutions are often asked to finance new plantations before they are established —and 
therefore long before their palm oil production can become RSPO certified-they cannot always rely on the RSPO certificate in their assessment process. Further elaboration on expanding a responsible policy for the oil palm sector to new plantations is given in 'The Palm Oil Financing Handbook' (Van Gelder and Taylor 2008).

\section{Criterion 5: How likely is the responsible} financing policy to have an impact on sustainable investments in the biofuel sector?

It is clear that public and private financiers could wield significant influence over the development of the global biofuel sector-which includes feedstock producers, biofuel producers and trading companies - if they were all to apply responsible financing policies and instruments to their financing decisions. There are, however, hundreds of financial institutions involved in financing biofuel developments in forest-rich countries (see paragraph 1.7.2) and not all have adopted (good) responsible financing policies and instruments.

Therefore, the likelihood that responsible financing policies and instruments will have a significant impact on improving the sustainability of biofuel investments depends on 2 elements: the quality of the responsible financing instruments and the dissemination of these instruments amongst financial institutions.

Quality. The quality of responsible financing instruments depends on the inclusion of clear criteria, preferably derived from international standards; the implementation in the financial institution's investment decision-making process; the scope of the instrument and the compliance and monitoring. If these elements are addressed adequately, these responsible financing instruments will certainly be able to guide a single financier's financing in the biofuel sector in a way that avoids deforestation.

Dissemination. To date, only a couple of dozen public and private financial institutions have implemented responsible financing policies and instruments for the biofuel, forestry and/or agriculture sectors that meet the quality criteria mentioned above. Many more financial institutions have issued or undersigned intentional statements or have adopted collective responsible financing instruments with a limited scope (i.e. the Equator Principles). When these financial institutions, as well as the large group that has taken no action at all, develop and implement responsible financing instruments that meet the quality criteria set above, the impact on developments in the biofuel sector could be very significant. To realise this potential, independent research showing the magnitude of the problem (e.g. Raitzer 2010) and external pressure by NGOs may be necessary, as shown in the Gunns example (Box 9).

\section{Box 9. Gunns pulp mill in Tasmania}

Gunns Limited, an Australian logging company, revealed plans to build a AUS\$2.2 billion pulp mill in Tasmania, Australia. The pulp mill would consume 4.5 million tonnes of wood every year, of which $80 \%$ would be sourced from Tasmania's native forests. Over 25 years, the pulp mill would lead to the destruction of at least 200000 hectares of irreplaceable native forests. As the pulp mill would also have negative consequences for the environment and for local employment, most Australians oppose it.

After conducting an independent assessment, ANZ, Gunns' long-term banker, announced in May 2007 that it would not be part of the project. Since then, the company has been looking for finance in vain. In April 2009, Australian NGO The Wilderness Society ran an advertisement in the Financial Times that included a list of banks that have refused to finance the project. In January 2010, Scandinavian bank Nordea, after initial discussions with Gunns, also refused to finance the pulp mill. Because of this failure, the strongest proponents of the project-John Gay and Robin Gray-were forced to step down from the board of Gunns in May 2010. The Wilderness Society believes this creates the opportunity to achieve permanent and lasting resolution to the conflict over forestry in Tasmania (TWS 2010).

\subsection{Options to improve responsible biofuel financing policies}

Realising the potential influence of private and public financiers on minimising the negative social and environmental costs associated with feedstock expansion and biofuel production requires improved dissemination of high-quality governance 
instruments amongst financiers. Furthermore, it is necessary that more banks and institutional investors, as well as state-owned companies and government agencies, adopt responsible financing instruments and that the quality of these instruments be improved.

Improving dissemination would mean that more private financial institutions would adopt and implement a number of responsible financing instruments, based on a responsible financing policy that defines which social and environmental conditions a company must meet before a financial institution will invest in it. Banks can expand their due diligence process to research whether their clients meet these criteria, they can discuss improvements with clients and include conditions in loan contracts, and they can monitor their clients. Institutional investors can screen the companies in whose shares and bonds they are considering investing, they can exclude certain companies, and they can engage with the companies in which they invest as well as voting in these companies' shareholder meetings.

Private and public financiers, both domestic and foreign, can tie social and environmental conditions to their investments in biofuel and related feedstock production. These social and environmental conditions need to be defined in a responsible biofuel financing policy, against which companies are screened. Conditions can be defined in financing agreements and the companies that are financed need to be monitored.

As the other essential element, improving the quality of governance instruments would mean the following, in concrete terms.

- Broad consensus is needed on a set of welldefined, verifiable criteria, preferably derived from international standards, which are of significance in shaping the economic, social and environmental impacts of biofuel and biofuel feedstock production. This set of criteria could serve as a model for the responsible financing policies of public and private financial institutions and the conditions that governments could tie to public finance. The proliferation of different sets of standards by various groups of actors is undesirable in this respect.

- Independent compliance and monitoring processes for all forms of private and public investments should be set up or improved, to strengthen the implementation of responsible financing policies and correct errors made.

- Private financiers should apply their responsible financing policies and related instruments to all forms of financing (including loans and other credits, underwriting, private equity and asset management), as well as to all companies involved in the biofuel supply chain.

- Governments - both in forest-rich production countries and in foreign countries - should adopt and implement responsible financing policies for all forms of public financing (e.g. subsidies, export credits, development loans and investments by state-owned companies) as well as for all financing in the entire biofuel supply chain (domestically and abroad).

Given the wide variety of financiers involved in financing the biofuel sector in forest-rich countries, as shown in our research, broader adoption and enhanced quality of responsible financing instruments by private and public financiers are crucially important for the sector's environmental and social sustainability. Conducting empirical research on the current impact of these instruments is very difficult, however, as many financial institutions do not publish lists of all companies they finance and certainly not of all companies they decline to finance. 


\section{Regulatory options to strengthen responsible financing}

\subsection{Introduction}

This chapter analyses regulatory options for governments to motivate or assist private financial institutions in developing and applying sound responsible financing policies, especially with regard to the financing of feedstock and biofuel production.

The first paragraph considers specific regulations that could require financiers to ascertain that companies producing feedstocks and/or biofuel meet certain social and environmental criteria, before they decide to finance them. The subsequent paragraphs examine how governments could motivate or assist private financial institutions in developing and applying generic responsible financing policies. Although this approach focuses on a wider problem than avoiding the financing of feedstock and biofuel production that has negative social and environmental impacts, it probably is more realistic and more achievable than a single-issue approach.

Paragraph 3.3 therefore discusses the existing international framework for financial regulation and paragraph 3.4 discusses recent developments and that which could help to integrate sustainability requirements into this regulatory framework. Paragraph 3.5 discusses some other regulatory options outside the strict domain of financial regulation that could help private financial institutions to develop and apply sound responsible financing policies.

\subsection{Direct regulations on biofuel financing}

In all jurisdictions throughout the world, corporate regulations only include obligations for the managers and owners of companies, not for their financiers. Many countries have regulations related to Environmental Impact Assessments, liability for damage done by corporations, GHG emissions or investments in feedstocks and biofuel production; hence, any companies planning to invest in feedstock or biofuel production must meet the requirements set out in these regulations.
However, in relation to financiers, only the private owners of (smaller) private companies and the governments owning government-owned companies can be held responsible for meeting requirements in these regulations. Providers of debt financing, such as banks, are never held responsible for meeting these obligations, nor are institutional investors that hold shares in a stock-exchange-listed company. In these cases, the responsibility for complying with regulations lies with the company's management; the financiers will be deemed to have no operational control over the company, and can therefore not be held responsible or liable (Richardson 2007).

Following are some of the few exceptions to this general situation, which make financiers liable for environmental damage caused by the company they finance or prohibiting them from financing certain companies.

- In the UK, since 2000, a secured lender, executing a charge and taking possession of the land, may be liable under the Environmental Protection Act for cleaning up contaminated land (McDermott et al. 2005).

- A law was adopted in Belgium in March 2007 that prohibits financial institutions from financing the production, trade and use of antipersonnel mines and cluster munitions (Netwerk Vlaanderen 2007).

The debate, around 10 years ago, on the European Environmental Liability Directive learned that the banking sector will strongly lobby to make financiers liable for environmental pollution caused by the companies they finance. This lender liability was the subject of intense debate. The European financial sector successfully argued that the concept of the 'operator'-which can be held liable for environmental damage — should be defined narrowly to exclude liability for the financiers of this operator (FBE 2002, 2003).

Indeed, the banking sector will resist one-issue or one-sector regulations as much as possible. As large banks are, by the nature of their activities, 
directly or indirectly involved in almost all sectors and all sustainability issues, one-issue or one-sector regulations could create a myriad of overlapping and partially contradicting requirements. To enhance efficiency and consistency, banks and other financial institutions would prefer generic regulations, fitting into the existing framework for financial regulation, on how they should deal with social and environmental issues. Options for such regulations are discussed in the following paragraphs.

\subsection{International framework for financial regulation}

Financial regulation aims to regulate the activities and conduct of the business of financial institutions, in order to limit and manage excessive risks both for these institutions and for other stakeholders. In general, companies operating in the financial sector are highly capable of assessing the amount and type of risk that they take. However, 3 main purposes justify the presence of financial regulation by governments (Brunnermeier et al. 2009):

1. to constrain the use of monopoly power, preventing distortions to competition and maintaining market integrity;

2. to protect the essential needs of ordinary people in cases where information is difficult or costly to obtain;

3. to avoid situations where the social and overall costs of market failure exceed both the private costs of failure and the extra costs of regulation.

Based on these purposes, financial regulation can be divided into 3 basic fields: prudential regulation, systemic regulation and conduct of business regulation (Goodhart et al. 1998). Each field has its own objectives, as follows.

Prudential regulation. The aim of prudential regulation is to ensure the safety and soundness of individual financial institutions. This is done by safeguarding the financial institution's capital and liquidity adequacy, as well as its risk management. How risks are assessed and managed in the global banking sector is determined to a large extent by the Basel Capital Accord II (BCA II) on capital requirements. This regulatory framework has been included in the financial legislation of almost all countries. The BCA II prescribes 2 credit risk assessment systems by which banks can assign credit risks to their investments; these in turn determine the amounts of capital to be reserved by the bank (BCBS 2004).

Systemic regulation. The argument that ensuring the soundness of each individual institution through greater prudential regulation ensures the soundness of the entire financial system is a fallacy: in trying to make themselves safer, financial institutions can behave in a way that collectively undermines the system (Brunnermeier et al. 2009). Therefore, systemic regulation is necessary. It aims to ensure financial stability and access to finance for businesses and other organisations, preventing the financial system from substantially prejudicing the economy as a whole. The existing financial supervision system's shortcoming is that there is a single market, with financial institutions operating across borders, but supervision remains uneven and often uncoordinated (De Larosière 2009). Initiatives have been taken to resolve this shortcoming; for example, the European Commission has adopted a proposal for the establishment of a European Systemic Risk Board to monitor and assess risks to the stability of the financial system as a whole (European Commission 2009a).

Conduct of business regulation. Conduct of business regulation ensures that financial institutions conduct business with their customers in a fair, transparent and honest way. This type of regulation protects only the customers of financial institutions, but not other stakeholders and interests that might be harmed by financial institutions or the companies and other clients they are financing. Existing laws in the domain of sustainability issues do not apply to the financial sector because law makers typically only assign responsibility for problems directly to companies that extract, consume and pollute (Richardson 2007). Although a wide range of sustainability guidelines and initiatives exist specifically for the financial sector (see chapter 2), these guidelines are considered 'voluntary' and thus offer no mechanism for ensuring compliance (Bridgeman and Hunter 2008).

During the past decade, environmental, peace and development organisations worldwide have provided numerous examples showing that major international banks invest in companies that cause 
harm to humans and the environment. These banks persistently seem to be unaware of the activities of the companies they finance.

In 'The Supervision of Cross-Border Banking', which lays down the globally accepted principles of supervision for international banking groups, the Basel Committee on Banking Supervision shifts the entire responsibility for verifying this onto the supervisors of the concerned country (BCBS 1996), although often these supervisors are insufficiently capable or willing to carry that responsibility-not only in Indonesia and Congo, but also (with respect to subprime mortgages) in the United States.

Financial regulation has no answer to this problem, because it is nationally organised and primarily self-regulatory. Supervision and regulation of the financial sector is bottom-up oriented, with the focus on ensuring that individual institutions and market actors are sound and do not violate regulatory requirements (Kapoor 2010). In an international context, governance requires inter-governmental cooperation through treaties and other agreements (Richardson 2007), but none of the local country regulators explicitly monitors the behaviour of local financial institutions in foreign markets-which is also becoming increasingly important for smaller banks. Local financial regulators only evaluate procedurally whether banks have a risk management system, but have no insight into the customers and products these banks have abroad. This task is left to foreign regulators, which in practice often means that no monitoring is taking place-because who exactly should monitor a loan from a US subsidiary of a Dutch bank to a finance company in Mauritius owned by a Chinese firm that is using the acquired funds to develop a copper mine in Zambia?

\subsection{Integrating sustainability in financial regulation}

In response to the financial crisis, an intensive discourse on the reform of financial regulation is taking place at an international level. Leading this discourse is the Group of Twenty (G20), which has grown into the most important international forum for discussions on strengthening the international financial system. A result of these discussions is the 'Framework for Strong, Sustainable and Balanced
Growth', which was presented at the Pittsburgh Summit in September 2009. This framework aimsamongst others - to strengthen prudential oversight, improve risk management, promote market integrity and reinforce international cooperation (Pittsburgh Summit 2009). The G20 has given the Financial Stability Board (FSB) — in which financial regulators from many countries work together-the task of monitoring whether all financial regulators in the world are working towards the full and consistent implementation of the agenda defined by the G20. This provides a strong incentive for harmonisation and leaves little room for individual countries to follow a different agenda. In addition, the FSB advises the G20 mostly on highly complex and technical matters such as capital buffers, solvency ratios, liquidity standards and counterparty risks.

Some of these proposals are further developed by the Basel Committee on Banking Supervision (BCBS), in which supervisors from 27 countries participate. The BCBS is working on a new version of the Basel Capital Accord (BCA), for which a consensus on the basic outline was reached in July 2010 (BCBS 2010) and on which the G20 reached agreement during the Seoul summit in November 2010. The third BCA prescribes higher capital requirements, particularly in the area of securitisation and re-securitisation (BCBS 2009).

In anticipation of the new BCA, the EU has been working on a series of directives (Capital Requirement Directives or CRDs) that sharpen the working rules for risk management and capital buffers. In addition, the EU is strengthening the cooperation between financial supervisory authorities of different countries and new institutions are created with more authority to intervene in financial regulation at the European level (European Commission 2009a).

The European Commission announced a proposal for the new BCA to be implemented in European legislation by June or July 2011. The proposal to implement Basel III at the EU level is referred to as the Capital Requirements Directive IV or CRD IV.

National governments are represented within all these international bodies through ministers or supervisors. According to BankTrack-a network 
of civil organisations dealing with the private financial sector-this representation gives national governments the opportunity to propose further integration of sustainability into financial regulation, which would strengthen financial regulation in the following ways (BankTrack 2010b).

Prudential regulation. Banks often have insufficient knowledge of their clients' business activities—and the sometimes very harmful consequences of these. Integrating sustainability criteria in investment policies strengthens risk management (Weber $e t$ al. 2010) leads to improved financial performance (Simpson and Kohers 2002, Mercer 2009).

Systemic regulation. Ignoring sustainability risks contributes to resource depletion, floods and other natural disasters caused by climate change, land right conflicts, labour disputes and, more generally, to social instability. This also has long-term implications for the financial system: financial stability is only achieved in a world that is not divided by conflict over the distribution of scarce resources.

Conduct of business regulation. More and more financial institutions present themselves as green and sustainable, despite insufficiently implementing sustainability criteria (Van Gelder et al. 2010). This misleads consumers who want to be sure that their savings and investment money are not used to finance companies that are causing particular harm to humans and the environment.

As concrete action, BankTrack has proposed that the following points be incorporated in the BCA (BankTrack 2010b).

- Through the Internal Ratings-Based (IRB) approach, the BCA provides banks with a considerable amount of freedom in deciding how to assess their credit risk. A new BCA should include that banks that wish to apply this approach are required to integrate sustainability criteria into their risk assessment system.

Investments based on sustainability criteria should be classified in different Probability of Default (PD) classes. This ensures the sustainability credentials of the bank's investment have a direct correlation with the capital buffer that the bank must retain.

- Investigation can take place-in collaboration with the banking sector-of the risks that banks run if they are insufficiently informed about the practices of their (foreign) customers, and how they can better assess their social risks and the correlation of these with banking risks (credit, reputation, integrity). An analysis of the credit defaults of banks could offer more insight into the expertise and the tools that a bank requires to properly assess its risks. Detailed regulations can be instituted based on this analysis.

- Moreover, banks should assess the PD of each financial product throughout its full term. When banks sell a financial product or the associated financial risk (e.g. in the form of securities, securitisation, CDS or other derivatives), they must be obliged to disclose the PD assessment to the buyers. To gain permission to adopt the IRB approach, banks must possess demonstrable knowledge and expertise in this area.

- In July 2009, the European Commission stated that potentially 'specific, very high capital requirements should be established for financial institutions to discourage foreign currency loans to private households' (European Commission 2009b). Such specific, very high capital requirements may also be established for loans with a very negative sustainability impact for which (e.g. due to government guarantees) the PD is still very low, as could be the case for investments in controversial weapons production.

- The definition of the new solvency ratio in the BCA should include sustainability criteria. A much higher solvency ratio should be applied to investments in activities with a very negative sustainability impact, such as speculative commodities trading (Kerckhoffs et al. 2010).

- The new European financial supervisory bodies should be tasked with building knowledge and expertise in the area of sustainability in the financial sector and to spread this amongst national supervisors. This should particularly address the manner in which supervisors can gain greater insight in the sustainability risks associated with the activities of banks in foreign markets.

Using the above proposals, which evidently need further development, the goal of achieving sustainable development in the biofuel sector and elsewhere can be implemented in the international framework for financial regulation. 
However, individual countries do not have to wait for such changes in the Basel Capital Accord to materialise- they can take their own steps to strengthen attention to sustainability factors in financial institutions' risk assessment procedures. In some Asian countries steps into this direction are already being taken, as follows.

- In the wake of the Asian financial crisis of 199798, the Indonesian banking regulator reached the conclusion that ignoring sustainability issues had a direct relationship with bad loans. As a result, Indonesian banks are now obliged to take their customers' environmental policies into account when assessing credit applications (Bank of Indonesia 2005).

- In China, the Green Credit Policy was introduced in July 2007. The government has established a 'credit blacklist' of companies that do not meet environmental standards through their high energy consumption, pollution or environmental risk and that Chinese banks should therefore avoid. The lack of disclosure on environmental issues makes it very difficult to analyse the real effectiveness of their policies, but some banks have indeed cut lending to polluting and energyintensive industries (Tracy 2010).

The scope of the regulations in both countries is limited: lending to foreign operations is not included and biodiversity risks do not play a large role. To address key environmental and social sustainability challenges in the biofuel sector, broader regulations are necessary.

\subsection{Other regulatory options}

\subsubsection{Motivating responsible investment amongst pension funds}

Since 2000, the SRI Pensions Disclosure Regulation requires pension schemes in the UK to disclose in their Statement of Investment Principles the extent to which they take into account social, environmental and ethical issues in their investment policies (Mathieu 2000). Although this has motivated UK pension funds to pay more attention to sustainability issues, additional regulation to require them to report on the implementation of their Statement of Investment Principles is lacking (Gribben and Gitsham 2006).

\subsubsection{Credit rating agencies}

In September 2009, the European Commission proposed to give authority for the registration and monitoring of credit rating agencies to the new European Securities and Markets Authority (ESMA) from early 2011 (European Commission 2009c). The ESMA involves the cooperation of various national regulators. Credit rating agencies play a crucial role in the investment decisions of many institutional investors (e.g. pension funds, insurers) and the banks that apply the standardised approach described in the Basel Capital Accord (BCA). Therefore, in the document setting out the ESMA's exact roles and responsibilities in this field, a clause should be inserted that states that credit rating agencies should have demonstrable knowledge and capacity for assessing sustainability risks and for incorporating these into their risk analysis. Preconditions regarding the sustainability expertise of credit rating agencies should also be recorded in the BCA.

\subsubsection{Corporate social responsibility reporting requirements}

To motivate financial institutions to invest responsibly, governments can require companies to be more transparent in relation to their social and environmental impacts. When considering investments in these companies, financial institutions can then make more informed decisions. Such regulations exist in France, Malaysia, South Africa and Sweden, although they often fail to cover biodiversity risks (Lydenberg and Grace 2008). Many governments support efforts by the Global Reporting Initiative (GRI) to further develop its sustainability reporting framework, which sets out the principles and indicators that organisations can use to measure and report their economic, environmental and social performance. However, not many countries have made the GRI guidelines mandatory for corporate reporting (GRI 2010). 


\section{Conclusions}

Various groups of financiers are involved in financing investments in biofuel feedstock growing and biofuel production in forest-rich countries in Asia, Africa and Latin America. In 20 country studies researched in a related project, an estimated US\$ 2.0-2.7 billion was invested in growing feedstocks for biofuel in the past 10 years. Investments in producing biofuel from these feedstocks were estimated at US\$ 5.7-6.7 billion since 2000 in the 20 country-feedstock pairs studied.

These investments were financed not only by private entrepreneurs, but also by public financiers (government subsidies, (multilateral) development loans and grants and investments by state-owned companies) and by private financial institutions (e.g. banks, asset managers, pension funds). Hundreds of private financial institutions were found to be involved, most of which are located outside the country where the investment took place. Several dozen public financiers play a significant role in the 20 case studies, many of which are also foreign.

Potentially, private and public financiers could have a strong influence on minimising the negative social and environmental costs associated with feedstock expansion and biofuel production. However, our findings suggest that most private and public financiers involved in financing feedstock and biofuel production are not yet effectively addressing key environmental and social sustainability challenges, either because they lack sustainability policies or because their policies are of insufficient quality:

- Only a few private financiers have developed a responsible financing policy for biofuel investments that contains verifiable and welldefined criteria. Where policies exist, they are not linked clearly to internationally accepted standards, and they lack transparent and effective internal monitoring and external compliance mechanisms.

- Amongst public financiers, only the multilaterals and a few foreign development banks have developed social and environmental policies that contain verifiable and well-defined criteria.
Multilateral development banks also have transparent and effective internal monitoring and external compliance mechanisms in place, but they play a significant financing role in only a few case studies. Most other government financiers, especially domestic and foreign state-owned companies, lack both policies and monitoring and compliance mechanisms.

Realising the potential influence of private and public financiers on minimising the negative social and environmental costs associated with feedstock expansion and biofuel production requires improved dissemination of high-quality governance instruments amongst various financiers. More banks and institutional investors, as well as state-owned companies and government agencies, should adopt responsible financing policies and instruments.

Furthermore, the quality of governance instruments needs to be enhanced. In concrete terms, this means the following.

- Broad consensus is needed on a set of welldefined, verifiable criteria, preferably derived from international standards, which are of significance in shaping the economic, social and environmental impacts of biofuel and biofuel feedstock production. This set of criteria could serve as a model for the responsible financing policies of public and private financial institutions and the conditions that governments could tie to public finance. The standards presently developed by the Roundtable on Sustainable Biofuels (RSB) could be further developed and tested, to serve as a model of responsible biofuel financing policy for all public and private financiers involved.

- Independent compliance and monitoring processes for all forms of private and public investments should be set up or improved to strengthen the implementation of responsible financing policies and correct errors made. These mechanisms should be financed by the financiers themselves.

- Private financiers should apply their responsible financing policies and related instruments to all 
forms of financing (including loans and other credits, underwriting, private equity and asset management), as well as to all companies involved in the biofuel supply chain.

- Governments-both in forest-rich production countries and in foreign countries—should apply responsible financing policies to all forms of public financing (e.g. subsidies, export credits, development loans and investments by stateowned companies) as well as to all investments in the biofuel supply chain (domestically and abroad).

Whilst the recommendations above could be adopted on a voluntary basis by all private and public financiers involved, governments also have regulatory options to motivate or assist private financial institutions in developing and applying sound responsible financing policies. It is not realistic to develop such regulations for the feedstock and biofuel sectors alone, or make financiers liable or responsible for the activities the companies they finance.

A more realistic approach would be to include generic requirements to develop and apply sound responsible financing policies in financial regulation. A few countries, such as Indonesia, China and the United Kingdom, have already taken steps in this direction.

As financiers for feedstock and biofuel production originate from many countries around the world, it would be most effective to include sustainability criteria in the international financial regulatory framework, especially the Basel Capital Accord (BCA). The new BCA III was agreed upon in November 2010, but implementation in EU and national legislation is still underway. This implementation process offers opportunities to include sustainability criteria in many countries' financial regulations.

Governments can also adopt regulations that demand increased sustainability reporting and transparency by biofuel companies, or motivate credit rating agencies to include sustainability issues in their credit ratings. When considering investments in these companies, financial institutions can then make more informed decisions. 


\section{References}

Action Aid 2010 Meals per gallon: the impact of industrial biofuels on people and global hunger. ActionAid UK, London.

Bank of Indonesia 2005 BI Regulation No. 7/2/ $\mathrm{PBI} / 2005$ concerning asset quality rating for commercial banks. BI, Jakarta, Indonesia.

BankTrack 2004 Principles, profits or just PR? Triple $P$ investments under the Equator Principles. BankTrack, Nijmegen, Netherlands.

BankTrack 2005 BankTrack welcomes UNEP FI plans to weed out 'free riders'. BankTrack, Nijmegen, Netherlands.

BankTrack 2010a New rules for Equator Principles, but no new commitments from banks. BankTrack, Nijmegen, Netherlands.

BankTrack 2010b Submission to the Basel Committee. BankTrack, Nijmegen, Netherlands.

Basel Committee on Banking Supervision (BCBS) 1996 The supervision of cross-border banking. BCBS, Basel, Switzerland.

Basel Committee on Banking Supervision (BCBS) 2004 International convergence of capital measurement and capital standards - A revised framework. BCBS, Basel, Switzerland.

Basel Committee on Banking Supervision (BCBS) 2009 Enhancements to the Basel II framework. http://www.bis.org/publ/bcbs157.htm (10 May 2011).

Basel Committee on Banking Supervision (BCBS) 2010 The Group of Governors and Heads of Supervision reach broad agreement on Basel Committee capital and liquidity reform package [press release].

Beer, T., Grant, T. and Campbell, P.K. 2007 The greenhouse and air quality emissions of biodiesel blends in Australia. Commonwealth Scientific and Industrial Research Organisation, Clayton South, Australia.

Bissell, R.E. and Nanwani, S. 2009 Multilateral development bank accountability mechanisms: developments and challenges. Manchester Journal of International Economic Law 6(1): 2-55.

BP 2010 BP Statistical review of world energy. BP, London.
Bridgeman, N.L. and Hunter, D.B. 2008 Narrowing the accountability gap: toward a new foreign investor accountability mechanism. Georgetown International Environmental Law Review 20: 187-236.

Brunnermeier, M., Crockett, A., Goodhart, C., Persaud, A. and Shin, H. 2009 The fundamental principles of financial regulation. International Centre for Monetary and Banking Studies (IMCB) and Centre for Economic Policy Research (CEPR), Geneva and London.

Buchanan, G.M. Butchart, S.H.M., Dutsonc, G., Pilgrim, J.D., Steininger, M.K., Bishop, K.D. and Mayaux, P. 2008 Using remote sensing to inform conservation status assessment: estimates of recent deforestation rates on New Britain and the impacts upon endemic birds. Ibis 141: 56-66.

Burley, H. and Bebb, A. 2010 Africa: up for grabs - the scale and impact of land grabbing for agrofuels. Friends of the Earth Europe, Brussels, Belgium.

Cortez, L. and Regis Leal, M. 2010 Why biofuels are important. In: Rosillo-Calle, F. and Johnson, F.X. (eds) Food versus fuel: an informed introduction to biofuels, 58-85. Zed Books, London and New York.

Cotula, L., Dyer, N. and Vermeulen, S. 2008 Fuelling exclusion? The biofuels boom and poor people's access to land. International Institute for Environment and Development (IIED), London.

Coulson, A B. 2009 How should banks govern the environment? Challenging the construction of action versus veto. Business Strategy and the Environment 18(3): 149-161.

De Larosière, J. 2009 Report on financial supervision by a high-level group of experts. European Commission, Brussels, Belgium.

Delucchi, M. 2006 Lifecycle analyses of biofuels. University of California, Davis, CA, USA.

ECA-Watch 2010 What are ECAs? http://www. eca-watch.org/eca/ecas_explained.html [accessed 16 March 2011].

Equator Principles 2010a The Equator Principles Association governance rules. Equator Principles Association, New York. 
Equator Principles. 2010b Home page. http:// www.equator-principles.com [accessed 16 March 2011].

European Commission 2009a Commission adopts legislative proposals to strengthen financial supervision in Europe [press release]. Brussels, Belgium.

European Commission 2009b Commission services staff working document - Possible further changes to the capital requirements directive. [Press release] Brussels, Belgium.

European Commission 2009c Proposal for a regulation of the European Parliament and of the Council establishing a European Securities and Markets Authority: COM (2009) 503 final. Brussels, Belgium.

European Union 2009 Directive 2009/28/EC of the European Parliament and of the Council of 23 April 2009 on the promotion of the use of energy from renewable sources and amending and subsequently repealing Directives 2001/77/ EC and 2003/30/EC. http://eurlex.europa. eu/ LexUriServ/LexUriServ.do?uri=OJ:L:2009:140:0 016:0062:EN:PDF [accessed 16 March 2011].

Fearnside, P.M. 2001 Soybean cultivation as a threat to the environment in Brazil. Environmental Conservation 28(1): 23-38.

Fédération Bancaire de l'Union Europeénne (FBE) 2002 Proposal for a directive on environmental liability with regard to the prevention and remedying of environmental damage - Position paper. FBE, Brussels, Belgium.

Fédération Bancaire de l'Union Europeénne (FBE) 2003 Letter to Margot Wallström on 14.05.03 European Parliament Resolution on draft environmental liability directive. FBE, Brussels, Belgium.

Fenton, E. 2009 Snake oil or climate cure: the effect of public funding on European bioenergy. Bioenergy and Forests Briefing Note No. 2. FERN, Gloucestershire and Brussels.

FERN 2008 Exporting destruction: export credits, illegal logging and deforestation. FERN, Moreton in Marsh and Brussels.

Fischer, G., Hizsnyik, E., Prieler, S., Shah, M. and van Velthuizen, H. 2009 Biofuels and food security. OPEC Fund for International Development (OFID) and International Institute for Applied Systems Analysis (IIASA), Vienna and Laxenberg, Austria.
Financial Times (FT) 20102010 FT Sustainable Banking Awards winners announced. Financial Times. 3 June.

German, L., Schoneveld, G., Skutch, M., Andriani, R., Obidzinski, K., Pacheco, P., Komarudin, H., Andrianto, A., Lima, M. and Dayang Norwana, A. 2010 The local social and environmental impacts of biofuel feedstock expansion - A synthesis of case studies from Asia, Africa and Latin America. CIFOR, Bogor, Indonesia.

Gerster, R. 2011 Sustainable finance: achievements, challenges, outlook. Gerster Consulting, Richterswil, Switzerland.

Giamporcaro, S., Pretorius, L. and Visser, M. 2010 Responsible investment: a vehicle for environmentally sustainable economic growth in South Africa? Discussion Paper Series EfD DP 10-17. Environment for Development, Cape Town, South Africa.

Global Bioenergy Partnership (GBEP) 2006 Italy leads the G8 to conclude the Global Bioenergy Partnership. July 2006.

Global Bioenergy Partnership (GBEP) 2010 GBEP progress report to the G20 Seoul Summit 2010. November 2010.

Global Bioenergy Partnership (GBEP) 2011 Purpose and functions. http://www. globalbioenergy.org/aboutgbep/purpose0/en/ [accessed 16 March 2011].

Global Reporting Initiative (GRI) $2010 \mathrm{http} / /$ www. globalreporting.org [accessed 16 March 2011].

Global Subsidies Initiative (GSI) 2008 Biofuels: at what cost? Government support for ethanol and biodiesel in China. GSI, Geneva, Switzerland.

Goodhart, C., Hartmann, P., Llewellyn, D.T., Rojas-Suarez, L., Weisbrod, S. 1998 Financial regulation: why, how and where now? Routledge, Oxon, UK.

Gootjes, K. and A. Herder 2009 Benchmark responsible investment by pension funds in the Netherlands 2009. The Dutch Association of Investors for Sustainable Development (VBDO), Culemborg, Netherlands.

Greenpeace 2008 Greenpeace challenges RSPO to stop green-washing member companies Prevents Sinar Mas palm oil tanker from loading at Dumai. Greenpeace, Pekanbaru, Indonesia.

Gribben, C. and Gitsham, M. 2006 Will UK pension funds become more responsible? A survey of trustees - 2006 edition. JustPensions, London. 
Hill, J., Nelson, E., Tilman, D., Polasky, S. and Tiffany, D. 2006 Environmental, economic, and energetic costs and benefits of biodiesel and ethanol biofuels. Proceedings of the National Academy of Sciences of the United States of America 103: 11206-11210.

Inter-American Development Bank (IDB) 2009a IDB releases new version of Biofuels Sustainability Scorecard. IDB, Miami, FL, USA.

Inter-American Development Bank (IDB) 2009b IDB Biofuels Sustainability Scorecard. IDB, Miami, FL, USA.

Inter-American Development Bank (IDB) 2010 IDB Biofuels Sustainability Scorecard. http:// www.iadb.org/biofuelsscorecard/ [accessed 16 March 2011].

International Finance Corporation (IFC) 2006a Performance standards on social and environmental sustainability. IFC, Washington, DC.

International Finance Corporation (IFC) 2006b Performance standard 6 - Biodiversity conservation and sustainable natural resource management. IFC, Washington, DC.

International Finance Corporation (IFC) 2010a Performance standard 6 - Rev 0.1 - Biodiversity conservation and sustainable natural resource management (draft). IFC, Washington, DC.

International Finance Corporation (IFC) 2010b IFC in the palm oil sector. http://www.ifc.org/ifcext/ agribusiness.nsf/content/palmoil?OpenDocumen t\&TableRow=1.1 [accessed 16 March 2011]

International Finance Corporation (IFC) 2011 Revised Draft World Bank Group framework and IFC strategy in the palm oil sector. IFC, Washington, DC.

Kapoor, S. 2010 The financial crisis: causes and cures. European Trade Union Institute, Brussels, Belgium.

Kerckhoffs, T., van Os, R. and Vander Stichele, M. 2010 Financing food: financialisation and financial actors in agriculture commodity markets. Stichting Onderzoek Multinationale Ondernemingen, Amsterdam, Netherlands.

Koh, L.P. and Wilcove, D.S. 2008 Is oil palm agriculture really destroying tropical biodiversity? Conservation Letters 1: 60-64.

Kutas, G., Lindberg, C. and Steenblik, R. 2007 Biofuels - At what cost? Government support for ethanol and biodiesel in the European Union. Global Subsidies Initiative, Geneva, Switzerland.
Lydenberg, S. and Grace, K. 2008 Innovations in social and environmental disclosure outside the United States. Domini Social Investments, New York.

Mathieu, E. 2000 Response of UK pension funds to the SRI disclosure regulation. Social Investment Forum, London.

McDermott, T. Stainer, A. and Stainer. L. 2005 Contaminated land: bank credit risk for small and medium size UK enterprises. International Journal for Environmental Technology and Management, 5(1): 1-13.

Mercer 2009 Shedding light on responsible investment: approaches, returns and impacts. Mercer, London.

Netwerk Vlaanderen 2007 The Belgian law that prohibits the financing of the production, trade and use of anti-personnel mines and cluster munitions: questions and answers. Netwerk Vlaanderen, Brussels, Belgium.

Norwegian Government Pension Fund (NGPF) 2009 Exclusion of metallurgical and mining company, NGPF, 19 November.

Norwegian Government Pension Fund (NGPF) 2010 Three companies excluded from the Government Pension Fund Global. NGPF, 23 August.

Norwegian Government Pension Fund (NGPF) 2011 Companies excluded from the investment universe. http://www.regjeringen.no/en/dep/fin/ Selected-topics/the-government-pension-fund/ responsible-investments/companies-excludedfrom-the-investment-u.html?id $=447122$ [accessed 16 March 2011].

Novethic Research 2011 Stakeholder engagement: a promising SRI practice. Novethic Research, Paris.

O'Sullivan, N. and O'Dwyer, B. 2009 Stakeholder perspectives on a financial sector legitimation process: the case of NGOs and the Equator Principles. Accounting, Auditing \& Accountability Journal 22(4): 553-587.

Office of the Compliance Officer (CAO) 2009 CAO audit of IFC's investments in: Wilmar Trading (IFC No. 20348) et al. Office of the Compliance Advisor/Ombudsman, Washington, DC.

Organisation for Economic Co-operation and Development (OECD) 2003 Recommendation on common approaches on environment and officially supported export credits. OECD, Paris.

Oxfam 2008 Another inconvenient truth: how biofuel policies are deepening poverty and 
accelerating climate change. Oxfam Briefing Paper No. 114. Oxfam, Oxford, UK.

Pena, N., Bird, N., Frieden, D. and Zanchi, G. 2010 Conquering space and time: the challenge of emissions from land use change. CIFOR, Bogor, Indonesia.

Perez, O. 2007 The new universe of green finance: from self-regulation to multi-polar governance. Bar Ilan University, Tel Aviv, Israel.

Peskett, L., Slater, R., Stevens, C. and Dufey, A. 2007 Biofuels, agriculture and poverty reduction. Natural Resource Perspectives No. 107. Overseas Development Institute, London. Pimentel, D., Marklein, A., Toth, M.A., Karpoff, M.N., Paul, G.S., McCormack, J.K. and Krueger, T. 2010 Why we should not be using biofuels. In: Rosillo-Calle, F. and Johnson, F.X. (eds) Food versus fuel: an informed introduction to biofuels, 29-57. Zed Books, London and New York

Pittsburgh Summit 2009 Leaders' statement: The Pittsburgh Summit. Conference in Pittsburgh, PA, USA, 24-25 September. http://www. pittsburghsummit.gov/mediacenter/129639.htm [accessed 16 March 2011].

Product Board for Margarine, Fats and Oils (MVO) 2009 Market analysis oils and fats for fuel. MVO, Rijswijk, Netherlands.

Rabobank 2010 Rabobank's position on biofuels. Rabobank International, Utrecht, Netherlands.

Ragwitz, M., Schade, W., Breitschopf, B., Walz, R., Helfrich, N., Rathmann, M., Resch, G., Panzer, C., Faber, T. and Haas, R. 2009 EmployRES: the impact of renewable energy policy on economic growth and employment in the European Union. Final report, contract no. TREN/D1/474/2006.

Raitzer, D. 2010 Assessing the impact of policyoriented research: the case of CIFOR's influence on the Indonesian pulp and paper sector. World Development 38(10): 1506-1518.

Ravindranath, N.H., R. Manuvie, J. Fargione, J.G. Canadell, G. Berndes, J. Woods, H. Watson, J. Sathaye. 2009 Greenhouse gas implications of land use and land conversion to biofuel crops. In: Howarth, R.W. and Bringezu, S. (eds.) Biofuels: environmental consequences and interactions with changing land use, 111-125. Cornell University, Ithaca, NY, USA.

Richardson, B.J. 2007 Financing sustainability: the new transnational governance of socially responsible investment. Yearbook of international environmental law 2007, 17(1), 73-110. Oxford University Press, Oxford.

Roberts, D. 2009 Securing finance for biofuels: where is the money coming from? Paper presented at World Biofuels Markets Conference, Brussels, Belgium, 16-18 March.

Rosillo-Calle, F. and Johnson, F.X. 2010 Introduction. In: Rosillo-Calle, F. and Johnson, F.X. (eds) Food versus fuel: an informed introduction to biofuels, 29-57. Zed Books, London and New York.

Roundtable on Sustainable Biofuels (RSB) 2010a Introduction to the RSB certification systems. RSB, Lausanne, Switzerland.

Roundtable on Sustainable Biofuels (RSB) 2010b Summary of changes from Version One to Version 2 of the RSB principles and criteria and synopsis of the public consultation on Version 1.1. RSB, Lausanne, Switzerland.

Roundtable on Sustainable Biofuels (RSB) 2011a Biofuel for thought: newsletter of the Roundtable on Sustainable Biofuels, Vol. 2 no. 2. RSB, Lausanne, Switzerland.

Roundtable on Sustainable Biofuels (RSB) 2011b Know your biomass: the RSB kicks off its certification system. RSB, Lausanne, Switzerland.

Schmidt, S. and Weistroffer, C. 2010 Responsible investments: a new investment trend here to stay. Deutsche Bank Research, Frankfurt, Germany.

Scholtens, B. 2006 Finance as a driver of corporate social responsibility. Journal of Business Ethics 68: 19-33.

Schoneveld, G. and German, L. 2010 Biofuels in Ghana: analysis of the legal and institutional framework. CIFOR Working Paper. CIFOR, Bogor, Indonesia.

Simpson, W.G. and Kohers, T. 2002 The link between corporate social and financial performance: evidence from the banking industry. Journal of Business Ethics 35: 97-109.

Standard Chartered Bank (SCB) 2010 Biofuels. Standard Chartered Bank, London.

Stockholm Environment Institute (SEI) and Humanist Institute for Development Cooperation (Hivos) 2008 Food, feed and fuels: consequences of land use change patterns for livelihoods of marginalised people in the South. Hivos and SEI, The Hague, Netherlands, and Somerville, MA, USA. 
Thomson One 2010 Project finance league tables. Thomson One database. https://www. thomsonone.com/ [accessed 16 March 2011].

Tracy, A. 2010 Sustainability versus stimulus: which way for China's banks? Investment and Pensions Asia, 17 June, p. 12.

The Wilderness Society (TWS) 2010 Gunns pulp mill proposal Tasmania. http://www.banktrack. org/show/dodgydeals/gunns_pulp_mill_ proposal_tasmania [accessed 16 March 2011].

United Nations Conference on Trade and Development (UNCTAD) 2009 The biofuels market: current situation and alternative scenarios. UNCTAD, Geneva and New York.

United Nations Environment Programme (UNEP) 2009 Towards sustainable production and use of resources: assessing biofuels. UNEP, Paris.

United Nations Environment Programme Finance Initiative (UNEP FI) 2006 Show me the money: linking environmental, social and governance issues to company value. UNEP FI Asset Management Working Group, Geneva, Switzerland.

United Nations Environment Programme Finance Initiative (UNEP FI) 2010 About UNEP FI. www.unepfi.org [accessed 16 March 2011].

United Nations Principles for Responsible Investment (UNPRI) 2010 Signatories to the principles for responsible investment. http://www.unpri.org/ signatories/ [accessed 16 March 2011].

United States Energy Information Administration, International Energy Statistics http://www.eia. doe.gov/cfapps/ipdbproject/IEDIndex3.cfm [March 2011].
Van Gelder, J. and Taylor, R. 2008 The palm oil financing handbook, WWF International, Gland, Switzerland.

Van Gelder, J. 2009 German and multilateral financial institutions in the bioenergy sector. German Platform for Sustainable Biomass, Berlin, Germany.

Van Gelder, J. and Herder, A. 2010 Close the gap: benchmarking investment policies of international banks. BankTrack, Nijmegen, Netherlands.

Van Gelder, J. and German, L. 2011 Biofuel finance: Global trends in biofuel finance in forest-rich countries of Asia, Africa and Latin America and implications for governance. CIFOR Infobrief 36. CIFOR, Bogor, Indonesia.

Van Putten, M. 2008 Policing the banks: accountability mechanisms for the financial sector. McGill-Queen's University Press, Montreal, Canada.

United Nations Environment Programme Finance Initiative (UNEPFI) 2005 A legal framework for the integration of environmental, social and governance issues into institutional investment. Freshfields Bruckhaus Deringer, London.

Weber, O., Scholz, R.W. and Michalik, G. 2010 Incorporating sustainability criteria into credit risk management. Business Strategy and the Environment 19(1): 39-50.

Zeller, T. 2010 Banks grow wary of environmental risks. New York Times, 30 August, p. A1. 

This report summarises 20 case studies on investments in the production of biofuel and the feedstocks used for biofuel (palm oil, soybeans, sugarcane and jatropha) in forest-rich countries in Africa, Asia and Latin America. The investments were financed by private entrepreneurs, public financing and private financial institutions. A large number of private financial institutions such as banks, asset managers and pension funds were investing, most of which are located outside the country where the investment took place. Dozens of public financial institutions-many of which are foreign-play a significant role.

Since the availability of finance is a crucial precondition for the further growth of the biofuel sector, these actors could play an important role in leveraging more sustainability in the sector. However, our findings suggest that most investors are not yet effectively addressing key environmental and social sustainability challenges, either because they lack sustainability policies or because their policies are of insufficient quality.

Realising the potential influence of investors on minimising the negative social and environmental costs associated with feedstock expansion and biofuel production requires improved dissemination of high-quality governance instruments. Whilst private and public investors could develop and adopt better policies voluntarily, we also discuss regulatory options available to governments in production and consumption countries. These options could motivate or assist private financial institutions in developing and applying sound, responsible financing policies.

\section{Profundo}

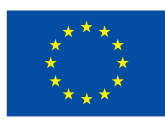
policies and practices that affect forests in developing countries. CIFOR is one of 15 centres within the Consultative Group on International Agricultural Research (CGIAR). CIFOR's headquarters are in Bogor, Indonesia. It also has offices in Asia, Africa and South America. 